\title{
Geochemical paleoredox indicators in organic-rich shales of the Irati Formation, Permian of the Paraná Basin, southern Brazil
}

\author{
Indicadores geoquímicos das condições paleoredox em \\ folhelhos ricos em matéria orgânica da Formação Irati, \\ Permiano da Bacia do Paraná, Sul do Brasil
}

\author{
Karin Goldberg ${ }^{1 *}$, Munir Humayun ${ }^{2}$
}

\begin{abstract}
Paleoredox indicators were used to assess the depositional environment of the Permian Irati Formation, and discuss the controls on the accumulation of organic-rich sediments. Geochemical data were measured for 43 drill-core samples in southern Paraná Basin. We infer that redox boundary was located at the sediment-water interface during the accumulation of these sediments. Trace-element data demonstrate that Irati shales were similar to average shales, except during deposition of two organic-rich beds in which $U$ and Mo are enriched, suggesting fully anoxic conditions. The variable degree of oxygenation of bottom waters is also attested by $\mathrm{DOP}_{\mathrm{T}}, \mathrm{Fe}_{\mathrm{T}} / \mathrm{Al}$, and sedimentological indicators of episodic ventilation. $\mathrm{DOP}_{\mathrm{T}}$ and $\mathrm{Fe}$ and $S$ correlation points to an iron-limited environment, where the main sulfur sink is organic matter rather than pyrite. $\mathrm{Cu}$ and $\mathrm{Cu} / \mathrm{Mo}$ ratio suggests bottom-water anoxia driven by increased organic flux. The Irati Formation was probably deposited in a salinity-stratified body of water, with positive water balance. The main control on the accumulation of the organic-rich sediments was the high organic carbon flux resultant from high primary productivity in surface waters. Anoxia arose as a consequence of increased productivity, not as the primary driver in the formation of these organic-rich rocks.
\end{abstract}

KEYWORDS: black shales; paleoredox proxies; Irati Formation; Permian.

\begin{abstract}
RESUMO: Indicadores da paleo-condiçäo redox foram utilizados para interpretar o ambiente deposicional da Formação Irati (Permiano) e discutir os controles na acumulação de sedimentos ricos em matéria orgânica. Os dados geoquímicos foram obtidos em 43 amostras de quatro testemunhos de sondagem de poços da Bacia do Paraná no Sul do Brasil. A interpretação desses dados permitiu inferir que a interface redox normalmente coincidia com a interface água-sedimentos durante a acumulação desses sedimentos. Dados de elementos-traços demonstram que os folhelhos da Formaçäo Irati eram similares ao folhelho médio, exceto durante a deposição de duas camadas ricas em matéria organica, caracterizadas por um grande enriquecimento em $U$ e Mo, o que sugere condiçóes completamente anóxicas durante a deposição dessas camadas. O variável grau de oxigenação das águas de fundo é também atestado pelo grau de piritização $\left(D O P_{T}\right)$, pela razão $\mathrm{Fe}_{T} / \mathrm{Al}$ e por indicadores sedimentológicos de aeração episódica (provavelmente decorrente de eventos de tempestade). $D O P_{T}$ e a correlaçäo entre Fe e $S$ sugerem um ambiente com limitação de ferro, onde a maior parte do enxofre está incluso na matéria orgânica e não na pirita. A razão entre Cu e Cu/Mo sugere que a anoxia de fundo foi consequência do alto fluxo orgânico. Assim, a Formação Irati provavelmente foi depositada em um corpo de água estratificado, com balanço hídrico positivo. O principal controle na acumulação de sedimentos ricos em matéria orgânica foi o alto fluxo de carbono resultante da alta produtividade primária em águas superficiais. Dessa forma, a anoxia foi uma consequência da alta produtividade, e não o principal controle na geração das rochas ricas em matéria orgânica.
\end{abstract}

PALAVRAS-CHAVE: folhelhos orgânicos; equivalentes paleoredox; Formaçáo Irati; Permiano.

${ }^{1}$ Kansas State University, Department Of Geology, Manhattan (KS), USA. E-mail: kgoldberg@ksu.edu

${ }^{2}$ Florida State University, Department of Earth, Ocean and Atmospheric Science \& National High Magnetic Field Laboratory, Tallahassee (FL), USA. E-mail: humayun@magnet.fsu.edu

*Corresponding author

Manuscript ID: 20160001. Received in: 01/04/2016. Approved in: 08/02/2016 


\section{INTRODUCTION}

Understanding the depositional settings of organic-rich sediments in the geological record is crucial to reconstructing the paleoclimate and paleohydrology of ancient sedimentary basins and in the prediction of the occurrence of oil source rocks (Demaison and Moore 1980, Calvert and Pedersen 1992, Arthur and Sageman 1994, Canfield 1994, Sladen 1994, Ganeshram et al. 1999, Carroll and Bohacs 2001, Sageman et al. 2003). In order to assess the physical-chemical conditions of ancient bodies of water (degree of oxygenation, salinity, and stratification of the water column) and thus draw a more complete picture of the primary controls on the accumulation of organics in fine-grained sediments, a variety of paleontological, sedimentological, and geochemical indicators has been used, including the degree of bioturbation, the presence of lamination, the absence of benthic fauna (e.g. Rhoads and Morse 1971, Ekdale and Mason 1988, Wignall and Myers 1988, Raiswell et al. 1988, Hatch and Leventhal 1992, Calvert and Pedersen 1993, Arthur and Sageman 1994, Sageman et al. 2003), as well as geochemical tests using biomarkers, stable isotopes, and trace elements (e.g. Meyers et al. 2005, Lyons and Severmann 2006, Tribovillard et al. 2006, Brumsack 2006, Algeo and Lyons 2006, Arnaboldi and Meyers 2007, Lehmann et al. 2007, Algeo and Maynard 2008, Huang et al. 2011, Trabucho-Alexandre et al. 2012, Pi et al. 2013).

The ongoing debate about the critical factor in the accumulation of organic matter involves, on one hand, bottom-water anoxia, leading to preferential preservation of organic carbon (e.g. Demaison and Moore 1980), and, on the other hand, increased organic flux to the sea floor as a consequence of high primary productivity, with redox boundary at the sediment-water interface (e.g. Meyers 2006, Arnaboldi and Meyers 2007, Trabucho-Alexandre et al. 2012). In the first case, hydrographic factors lead to the development of watercolumn anoxia in a basin, e.g., an enclosed basin with positive water balance, coastal upwelling, or a deep basin with an oxygen minimum zone (Arthur and Sageman 1994). In the latter, anoxia would be a consequence of the increased organic flux (Gallego-Torres et al. 2007, Goldberg et al. 2007, Joachimski et al. 2001, Kakuwa 2008, Berrocoso et al. 2010, Reolid et al. 2012, Stein et al. 2012, Xiong et al. 2012). The redox classification of the depositional environments adopted here is that of Tyson and Pearson (1991). Oxic environments are where oxygen concentration is greater than $2 \mathrm{ml} \mathrm{O} / 1 \mathrm{H}_{2} \mathrm{O}$ in bottom waters, suboxic, between 2 and $0.2 \mathrm{ml} \mathrm{O}_{2} / 1 \mathrm{H}_{2} \mathrm{O}$, and anoxic, where there is less than $0.2 \mathrm{ml}$ $\mathrm{O}_{2} / 1 \mathrm{H}_{2} \mathrm{O}$ and no free $\mathrm{H}_{2} \mathrm{~S}$ in the water column. Euxinic waters are defined as having $\mathrm{O}_{2}$ concentration equals to zero and free $\mathrm{H}_{2} \mathrm{~S}$ in the water column.
Redox-sensitive elements (e.g., V, Fe, Mn, Mo, U) are those elements that geochemically behave differently under oxic and anoxic conditions due to changes in the solubility of their oxyanions (Morford et al. 2005). The differential response of these elements to redox conditions enables their use for inferring the degree of oxygenation of the water where these sediments form. Redox-sensitive trace metals such as $\mathrm{V}, \mathrm{Cr}, \mathrm{Ni}, \mathrm{Cu}, \mathrm{Zn}, \mathrm{Mo}, \mathrm{Cd}$, and $\mathrm{U}$ tend to be more soluble under oxidizing conditions and less soluble under reducing conditions, resulting in authigenic enrichments in oxygen-depleted sedimentary facies (Tribovillard et al. 2006). The removal of these metals from seawater as sulfides $(\mathrm{Ni}$, $\mathrm{Zn}, \mathrm{Cu}, \mathrm{Mo}, \mathrm{Cd}$ ) or oxides/oxyhydroxides (V, Cr, Mo, U) under anoxic conditions results in enrichments of several orders of magnitude above detrital values in the mudrocks (Calvert and Pedersen 1993, Crusius et al. 1996, Morford and Emerson 1999, Algeo and Lyons 2006, Tribovillard et al. 2006, Arnaboldi and Meyers 2007, Algeo and Maynard 2008). The combined use of $U, V$, and Mo enrichments may allow the distinction between suboxic from anoxic-euxinic environments. These elements are more strongly enriched in anoxic-euxinic settings, with weaker covariation with total organic carbon (TOC) than in suboxic settings (Tribovillard et al. 2006). Mo has been widely used in paleoceanographic studies as a redox proxy (e.g., Emerson and Huested 1991, Jones and Manning 1994, Crusius et al. 1999, Morford et al. 2001, Piper and Dean 2002, Algeo et al. 2004, Algeo and Lyons 2006).

$\mathrm{Ni}$ and $\mathrm{Cu}$ are good proxies for organic carbon sinking flux (paleoproductivity), and may be used to determine whether bottom-water oxygenation and/or organic matter flux was the primary control on the development of reducing conditions (Tribovillard et al. 2006). Enrichments in U, V and Mo suggest anoxic bottom waters. If enrichments in these metals are also coupled with enrichments in $\mathrm{Ni}$ and $\mathrm{Cu}$, anoxia is accompanied by a high organic flux. Fe can be enriched under anoxic conditions through the precipitation as pyrite (Algeo and Maynard 2008).

The degree of pyritization of iron (DOP) has been proposed as a paleoenvironmental indicator of bottom-water oxygenation (Raiswell et al. 1988). It is defined as the ratio between pyrite-bound iron and total iron $\left(\mathrm{DOP}=\mathrm{Fe}_{\mathrm{py}} / \mathrm{Fe}_{\text {total }}\right)$, where total $\mathrm{Fe}$ is the sum of pyritic $\mathrm{Fe}$ and $\mathrm{HCl}$-soluble $\mathrm{Fe}$ (derived from detrital clays and oxides). In anoxic settings, pyrite formation is enhanced by organic content and efficient bacterial sulfate reduction, yielding high DOP values (Raiswell et al. 1988). Under normal oxic seawater conditions, pyrite can be formed below the sediment-water interface. However, pyrite formation is inhibited by the oxidation of organic matter, which inhibits bacterial sulfate reduction and thus the formation of $\mathrm{H}_{2} \mathrm{~S}$. Moreover, preservation of 
the pyrite formed is difficult due to the intense bioturbation of the sediments by bottom dwellers and oxidation of pyrite to Fe oxides. For these reasons, DOP values are typically low in oxic settings (Raiswell et al. 1988). $\mathrm{DOP}_{\mathrm{T}}$ is the ratio of pyrite Fe (based on total S) to total Fe (Algeo and Maynard 2008). This index can be used in place of true DOP, if pyrite $S$ composes the bulk of total $S$ and reactive Fe composes the bulk of total Fe. $\mathrm{DOP}_{\mathrm{T}}$ values for aerobic conditions are typically less than 0.3 , for restricted conditions, between 0.3 and 0.6 , and for inhospitable conditions, $\mathrm{DOP}_{\mathrm{T}}$ is usually greater than 0.6 (Algeo and Maynard 2008).

Lyons and Severmann (2006) established that the ratio of $\mathrm{Fe}_{\mathrm{T}} / \mathrm{Al}$ is an unambiguous recorder of paleoredox conditions. High $\mathrm{Fe}_{\mathrm{T}} / \mathrm{Al}$ and high DOP are the most faithful indicators of euxinia. $\mathrm{Fe}_{\mathrm{T}} / \mathrm{Al}$ less than 0.5 and DOP less than 0.2-0.3 suggest oxic-suboxic conditions, whereas $\mathrm{Fe}_{\mathrm{T}} / \mathrm{Al}$ greater than 0.5 and DOP greater than 0.6 point to euxinic conditions (Lyons and Severmann 2006). Intermediate DOP could be due to reducing conditions in pore waters beneath oxygenated bottom waters, or euxinic deposition at sites with high sedimentation rates.

The Irati black shales in the Paraná Basin comprise oil source rocks and a widespread marker across Gondwanan basins (Oelofsen 1987, França et al. 1995). Here, we report redox-sensitive elements, $\mathrm{C}$ isotopes, TOC, and sulfur content in the Permian Irati Formation, and use paleoredox proxies such as enrichment factor $(\mathrm{EF}), \mathrm{DOP}_{\mathrm{T}}$, and $\mathrm{Fe}_{\mathrm{T}} / \mathrm{Al}$ to assess the depositional environment of these shales and discuss the environmental controls on the accumulation of organic-rich sediments in the context of other geological evidence. These are relevant issues because the Irati oil shales have large potential for economic development in Brazil due to their accessibility, grade, and widespread distribution.

\section{SAMPLES AND ANALYTICAL METHODS}

\section{Geological setting and sampling}

The intracratonic Paraná Basin is the South American extension of a larger Permian basin developed in the interior of Gondwana (Fig. 1a) (Milani et al. 1994, 1998, 2007). The Permian in the Paraná Basin comprises seven third-order sequences that recount the oscillations of relative sea level (Goldberg 2001). During the Early Permian, such oscillations were driven initially by the advance and retreat of glaciers (sequences 1 and 2), succeeded by base level shifts due to isostatic rebound (sequence 3), tectonic reactivation (sequences 4 and 5), and continuous subsidence of the basin, leading to a relative sea level rise in the Middle
Permian (Fig. 2). A monotonic relative sea level fall and consequent continentalization of the basin followed (sequences 6 and 7), as a result of the combined effects of basin filling and climate change in the Late Permian and Early Triassic.

The black shales of the Permian Irati Formation in the Paraná Basin were deposited within the interval of maximum transgression of a second-order depositional sequence, under low sedimentation rates (Fig. 2). In addition to the oil shales, the Irati Formation also comprises carbonates and non-bituminous shales and claystones. SHRIMP zircon age dating from bentonitic tuffs intercalated with the Irati black shales yielded an age of 278.4 2.2 Ma (Santos et al. 2006), placing the Irati Formation in the Lower Permian (Artinskian).

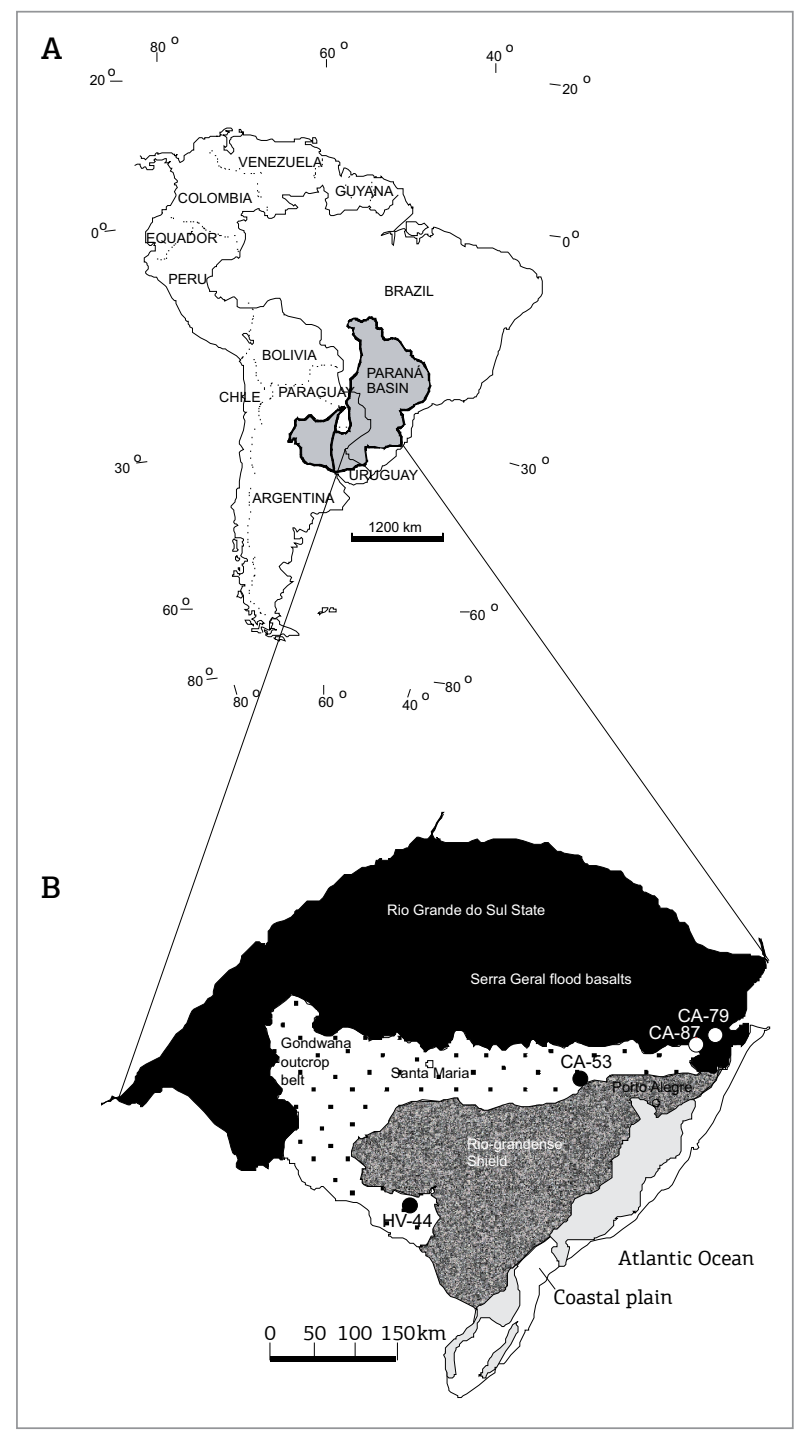

Figure 1. Geographic localization of the Paraná and Chaco-Paraná Basins in South America (after Zalan et al. 1990) (a), and the drill cores sampled for geochemical analyses in southern Paraná Basin (b). 
The black shales are rhythmically intercalated with limestones and dolomites, and individual beds vary from mm-scale laminae to meter-thick beds. Black shales consist of saponite or saponite-talc mixed layers, talc, lizardite,

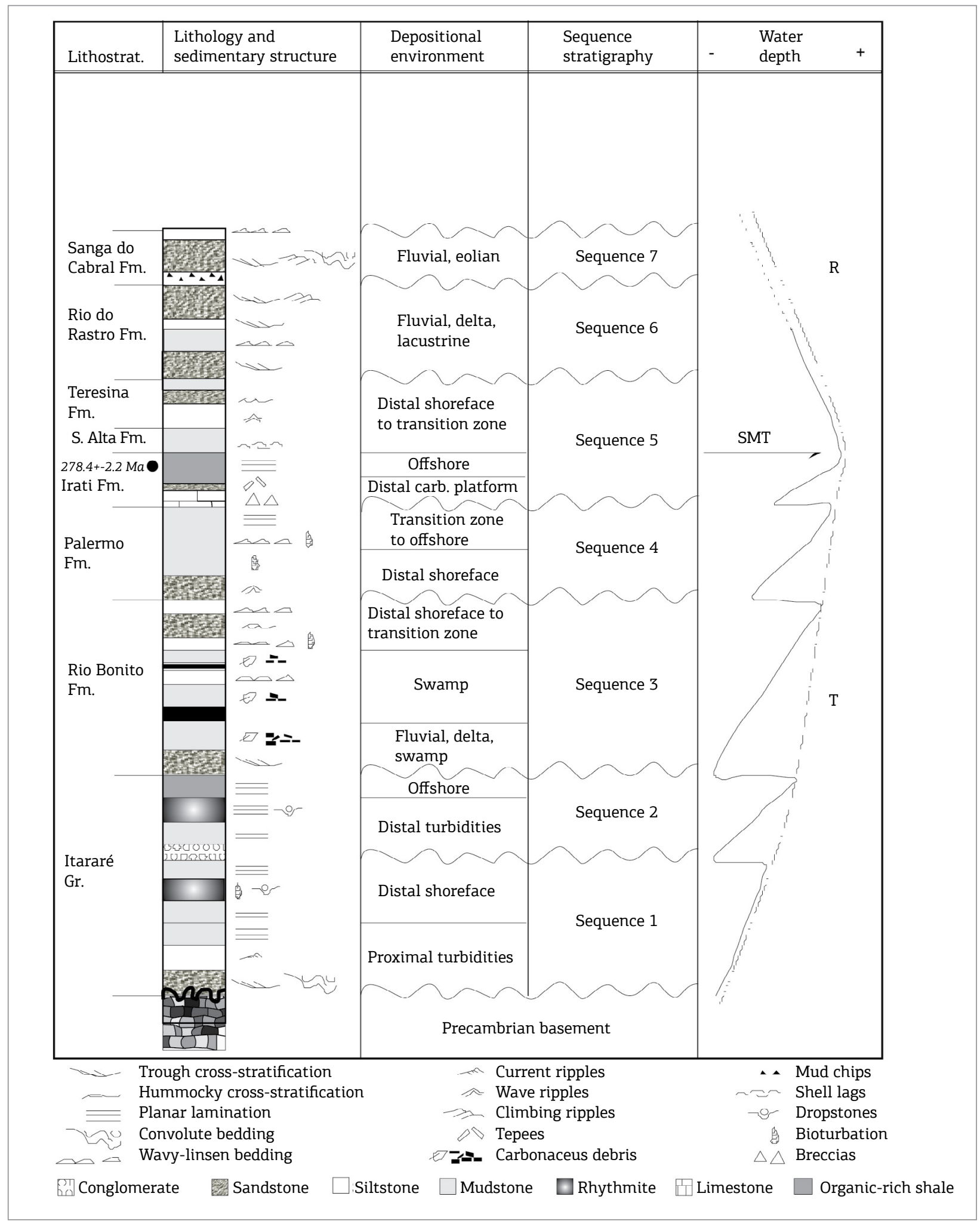

Figure 2. Summary chart of the depositional environments and sequences in the Permian section of the studied drill cores, with interpretation of the water depth (SMT = surface of maximum transgression, $\mathrm{T}=$ transgressive, $\mathrm{R}=$ regressive). Radiometric age in tuffs of the Irati Formation (278.4 $\pm 2.2 \mathrm{Ma}$ ) from Santos et al. (2006). 
nontronite, and quartz (Anjos et al. 2010). Green claystones are nontronite-rich but also contain lizardite, talc, and quartz, suggesting that sediment sources included altered basic-ultrabasic rocks (Anjos et al. 2010).

In Southern Brazil, two distinct oil-rich beds have an average thickness of $8 \mathrm{~m}$ (the lower bed) and $4 \mathrm{~m}$ (the upper one). These organic-rich layers contain $20-30 \%$ organic material and yield $2-12 \%$ recoverable oil on destructive distillation (Correa da Silva and Cornford 1985). The Irati shales are immature (lignite/sub-bituminous rank), oil-rich (100-114 kg/ton), and contain kerogen of a dominantly bacterially degraded algal origin (Correa da Silva and Cornford, 1985).

The Irati Formation has been regarded as deposited in an anoxic, epicontinental sea by most workers (e.g. Lavina et al. 1991, Triguis et al. 1996), but there has been substantial debate about the salinity of the water and the presence of stratification in the water column. Some authors consider that the Irati Formation could represent a coastal succession formed in a lagoon or gulf with variable salinity (Araújo 2001). Sedimentological and paleontological data obtained previously have been insufficient to resolve the depositional setting in which these rocks were formed (e.g. Correa da Silva and Cornford 1985, Mello et al. 1993).

Four cores drilled by the Brazilian Geological Survey in southern Paraná Basin were sampled (Fig. 1b). Three of them (CA-53, CA-79, and CA-87) were sampled at coarse intervals $(5-10 \mathrm{~m})$ throughout the extent of the Irati Formation, and a fourth core (HV-44), with greater TOC content, was sampled at a much finer scale, in some portions every 40 centimeters. Based on the TOC content, 21 samples from $\mathrm{HV}-44$ were selected to represent both the background sedimentation and the two organic-rich layers. Strata adjacent to diabase sills or portions that might have been affected by hydrothermal activity (i.e. crosscut by carbonate veins) were avoided during sampling. Samples that had carbonate content greater than $50 \%$ were not analyzed.

\section{Redox-sensitive element analysis}

Redox-sensitive elements were determined at the University of Chicago by Inductively Coupled Plasma Mass Spectrometry (ICP-MS). Rock chips (1-3 g) were ultrasonically cleaned with $18 \mathrm{M} \Omega$ deionized water and hand ground in an alumina mortar. Further sample preparation was carried out in a Class 100 laboratory supplied with HEPA-filtered air. Sample preparations were performed in Class 100 laminar flow acid exhaust hoods using Seastar ${ }^{\mathrm{TM}}$ double-distilled acids and 18.3 $\mathrm{M} \Omega$ deionized water. Approximately $200 \mathrm{mg}$ powder was weighed into acid-washed $15 \mathrm{ml}$ Savillex ${ }^{\mathrm{Tm}}$ teflon PFA digestion vessels with $3 \mathrm{ml}$ of $\mathrm{HF}$ and $2 \mathrm{ml}$ of $\mathrm{HCl}$, closed and heated on a hot plate at $160^{\circ} \mathrm{C}$ for 12 hours. The vessels were then opened and evaporated to dryness. The solid residue was taken up in $2 \mathrm{ml}$ of perchloric acid $\left(\mathrm{HClO}_{4}\right)$ and fumed to remove silicon. After the perchloric acid drydowns, the solids were dissolved in $6 \mathrm{ml}$ of $8 \mathrm{~N} \mathrm{HNO}_{3}$, closed and heated on a hot plate for 12 hours. The solutions were then diluted, centrifuged to remove any residue, and transferred to acid-washed Nalgene ${ }^{\mathrm{TM}} 125 \mathrm{ml}$ LDPE bottles. Any residual material (mainly alkali perchlorate) was dissolved with $6 \mathrm{~N} \mathrm{HCl}$ or $8 \mathrm{~N} \mathrm{HNO}_{3}$ by heating for 12 hours. The solutions were subsequently diluted with $2 \% \mathrm{HNO}_{3}$ for analysis by ICP-MS. Procedural blanks were negligible $(<<1 \%)$ for the elements analyzed.

Elemental abundances were determined using a Finnigan Element $^{\mathrm{TM}}$ high-resolution, magnetic sector ICP-MS, operating in low $(\mathrm{R}=340)$ and medium mass resolution $(\mathrm{R}=4300)$ modes. During the course of the measurements, instrumental sensitivity at ${ }^{115} \mathrm{In} \sim$ was $1-2$ million $\mathrm{cps} / \mathrm{ppb}$ in low resolution, and about a factor of 10 lower at medium resolution. The peaks determined in low resolution were ${ }^{51} \mathrm{~V},{ }^{53} \mathrm{Cr},{ }^{59} \mathrm{Co},{ }^{60} \mathrm{Ni},{ }^{63} \mathrm{Cu},{ }^{66} \mathrm{Zn},{ }^{95} \mathrm{Mo},{ }^{111} \mathrm{Cd}$, ${ }^{118} \mathrm{Sn},{ }^{182} \mathrm{~W}$, and ${ }^{238} \mathrm{U}$. Molecular isobaric interferences (on $\left.{ }^{51} \mathrm{~V},{ }^{53} \mathrm{Cr}\right)$ and instrumental blanks from the Ni cones $\left({ }^{60} \mathrm{Ni}\right.$, ${ }^{63} \mathrm{Cu},{ }^{66} \mathrm{Zn},{ }^{118} \mathrm{Sn}$ ) were subtracted from measured intensities by running a blank $2 \% \mathrm{HNO}_{3}$ solution. The choices of minor isotopes for $\mathrm{Ni}, \mathrm{Zn}, \mathrm{Mo}$, and $\mathrm{Cd}$ were influenced by the presence of (unresolvable) atomic ion interferences, particularly $\mathrm{Sn}$ on $\mathrm{Cd}$ at $\mathrm{m} / \mathrm{e}=112,114$. The peaks determined in medium resolution were ${ }^{25} \mathrm{Mg},{ }^{27} \mathrm{Al},{ }^{44} \mathrm{Ca},{ }^{49} \mathrm{Ti},{ }^{55} \mathrm{Mn}$, and ${ }^{56} \mathrm{Fe}$, the latter four elements being seriously affected by molecular interferences. External standardization with $2 \% \mathrm{HNO}_{3}$ solutions containing known concentrations of the measured elements, prepared by dilution from Spex ${ }^{\text {тм }}$ monoelement solutions, was used. The sample solutions were sufficiently dilute that samples and standards were considered to be matrix matched.

Two USGS standards (Marine Sediment MAG-1 and Cody Shale SCo-1) were prepared and analyzed in order to estimate the accuracy of these measurements. For all the major elements, the concentrations obtained were within the variation range reported by the USGS (Table 1). For the trace elements, the measured concentrations were within $10 \%$ of the values reported for the USGS standards, except for Mo and U (Table 2). The concentrations of these elements were consistently higher by a factor of two $(\mathrm{U})$ to three (Mo) than the ones reported by the USGS. The reasons for these discrepancies are not known.

\section{Total organic carbon, sulfur, and C isotopes}

TOC and sulfur content were measured at the Biogeochemistry Laboratory, at Indiana University. Rock chips $(1-3 \mathrm{~g})$ were ground by hand in agate mortars. For TOC 
Paleoredox indicators in the Permian Irati shales

Table 1. Major elements, C isotopes, Total Organic Carbon and S content, Degree of Pyritization and FeT/Al ratio in samples of the Irati Formation. (See Figure 1 for locations; sample labels refer to depth down core in meters).

\begin{tabular}{|c|c|c|c|c|c|c|c|c|c|c|c|c|}
\hline Core & Sample & $\begin{array}{c}\mathrm{Ti} \\
\text { (wt\%) }\end{array}$ & $\begin{array}{c}\mathrm{Al} \\
(\mathrm{wt} \%)\end{array}$ & $\begin{array}{c}\mathrm{Ca} \\
(\mathbf{w t} \%)\end{array}$ & $\begin{array}{c}\text { Mg } \\
(w t \%)\end{array}$ & $\begin{array}{c}\mathrm{Fe} \\
(\mathrm{wt} \%)\end{array}$ & $\underset{\text { (wt }}{\text { Mn }}$ & $\begin{array}{c}\text { TOC } \\
\text { (wt\%) }\end{array}$ & $\begin{array}{l}\text { S total } \\
\text { (wto) }\end{array}$ & DOP $_{T}$ & $\mathrm{Fe}_{\mathrm{T}} / \mathrm{Al}$ & $\begin{array}{l}\delta^{13} \mathrm{C} \\
(\%)\end{array}$ \\
\hline \multirow{6}{*}{ CA-53 } & 261,7 & 0,4 & 7,94 & 0,68 & 1,29 & 3,21 & 0,04 & 0,53 & 0,24 & 0,07 & 0,4 & \\
\hline & 271,4 & 0,4 & 7,6 & 0,1 & 1,26 & 3,62 & 0,04 & 0,66 & 0,24 & 0,06 & 0,48 & \\
\hline & 276,3 & 0,44 & 8 & 0,81 & 1,13 & 3,13 & 0,04 & 0,78 & 0,089 & 0,02 & 0,39 & \\
\hline & 291,5 & 0,41 & 7,34 & 1,71 & 0,93 & 2,06 & 0,14 & 0,42 & 0,086 & 0,04 & 0,28 & $-22,53$ \\
\hline & 294,7 & 0,42 & 6,47 & 0,59 & 1,4 & 2,85 & 0,1 & 0,5 & 0,044 & 0,01 & 0,44 & $-22,55$ \\
\hline & 298,6 & 0,47 & 7,49 & 0,6 & 1,46 & 4,74 & 0,1 & 1,61 & 0,45 & 0,08 & 0,63 & \\
\hline \multirow{9}{*}{ CA-79 } & 595,3 & 0,46 & 7,07 & 1,44 & 2,93 & 3,89 & 0,17 & 0,29 & 0,3 & 0,07 & 0,55 & $-23,67$ \\
\hline & 636,1 & 0,45 & 7,93 & 0,59 & 1,51 & 3,92 & 0,09 & 0,39 & 0,45 & 0,1 & 0,49 & $-22,59$ \\
\hline & 681,4 & 0,35 & 6,71 & 0,62 & 0,93 & 2,49 & 0,05 & 0,52 & 0,3 & 0,11 & 0,37 & \\
\hline & 685,5 & 0,4 & 7,26 & 0,86 & 1,07 & 2,03 & 0,11 & 0,31 & 0,14 & 0,06 & 0,28 & $-21,61$ \\
\hline & 694,7 & 0,34 & 6,07 & 0,44 & 0,85 & 2,44 & 0,04 & 0,55 & 0,32 & 0,11 & 0,4 & \\
\hline & 698,3 & 0,4 & 7,28 & 0,49 & 1,09 & 2,72 & 0,05 & 0,59 & 0,41 & 0,13 & 0,37 & \\
\hline & 723,6 & 0,46 & 8,21 & 0,55 & 1,16 & 3,38 & 0,04 & 1,25 & 0,63 & 0,16 & 0,41 & \\
\hline & 728,5 & 0,5 & 6,94 & 0,68 & 0,89 & 2,82 & 0,07 & 0,36 & 0,12 & 0,04 & 0,41 & $-23,5$ \\
\hline & 730,5 & 0,48 & 7,46 & 0,59 & 0,9 & 2,8 & 0,03 & 0,33 & 0,14 & 0,04 & 0,38 & \\
\hline \multirow{7}{*}{ CA-87 } & 437,5 & 0,39 & 6,29 & 3,26 & 2,2 & 2,65 & 0,19 & 0,18 & 0 & 0 & 0,42 & $-22,62$ \\
\hline & 489,6 & 0,43 & 7,59 & 0,8 & 1,39 & 3,96 & 0,11 & 0,43 & 0,23 & 0,05 & 0,52 & -23 \\
\hline & 500 & 0,27 & 5,63 & 0,46 & 0,72 & 2,41 & 0,04 & 0,54 & 0,64 & 0,23 & 0,43 & \\
\hline & 507 & 0,36 & 7,81 & 0,68 & 1,55 & 4,73 & 0,06 & 0,41 & 0,44 & 0,08 & 0,61 & \\
\hline & 512 & 0,41 & 7,57 & 0,62 & 1,29 & 3,31 & 0,04 & 0,64 & 0,46 & 0,12 & 0,44 & \\
\hline & 516 & 0,39 & 7,28 & 0,67 & 1,84 & 5,2 & 0,05 & 0,75 & 1,09 & 0,18 & 0,71 & \\
\hline & 520,2 & 0,4 & 6,65 & 0,85 & 1,35 & 3,38 & 0,09 & 0,59 & 2,18 & 0,56 & 0,51 & $-22,62$ \\
\hline \multirow{23}{*}{ HV-44 } & 232 & 0,45 & 8,02 & 1,18 & 1,25 & 3,17 & 0,04 & 0,72 & 0,18 & 0,05 & 0,4 & \\
\hline & 233 & 0,36 & 6,99 & 0,58 & 1,21 & 4,47 & 0,03 & 3,81 & 2,65 & 0,52 & 0,64 & \\
\hline & 234 & 0,35 & 7,1 & 1,08 & 1 & 3,72 & 0,03 & 7,03 & 1,9 & 0,44 & 0,52 & \\
\hline & 235 & 0,39 & 6,41 & 1,01 & 1,01 & 4,78 & 0,05 & 4,28 & 2,65 & 0,48 & 0,75 & \\
\hline & 236 & 0,27 & 7,83 & 1,38 & 1,05 & 2,5 & 0,03 & 2,85 & 1,68 & 0,59 & 0,32 & \\
\hline & 238 & 0,32 & 6,16 & 2,16 & 0,89 & 4,41 & 0,04 & 1,02 & 2,56 & 0,51 & 0,72 & \\
\hline & 249,6 & 0,39 & 8,29 & 1,37 & 1,44 & 3,33 & 0,04 & 0,47 & 0,65 & 0,17 & 0,4 & \\
\hline & 250,8 & 0,42 & 7,9 & 0,8 & 1,32 & 3,75 & 0,04 & 3,07 & 1,74 & 0,4 & 0,47 & \\
\hline & 252 & 0,42 & 7,8 & 0,92 & 1,29 & 3,76 & 0,06 & 0,65 & 1,24 & 0,29 & 0,48 & \\
\hline & 253,2 & 0,39 & 7,47 & 1,01 & 1,33 & 4,46 & 0,04 & 1,56 & 2,38 & 0,46 & 0,6 & \\
\hline & 253,6 & 0,33 & 5,88 & 0,92 & 1,02 & 7,1 & 0,03 & 6,17 & 4,05 & 0,5 & 1,21 & \\
\hline & 254 & 0,28 & 5,37 & 0,97 & 0,91 & 6 & 0,03 & 9,46 & 4,75 & 0,69 & 1,12 & \\
\hline & 254,8 & 0,32 & 7,43 & 1,21 & 1,36 & 4,72 & 0,05 & 1,91 & 3,65 & 0,67 & 0,64 & \\
\hline & 255,2 & 0,28 & 5,47 & 0,8 & 0,81 & 5,35 & 0,03 & 13 & 4,37 & 0,71 & 0,98 & \\
\hline & 255,6 & 0,36 & 6,76 & 0,44 & 1,18 & 4,2 & 0,05 & 10,1 & 3,28 & 0,68 & 0,62 & \\
\hline & 256 & 0,37 & 5,68 & 0,56 & 0,91 & 5,01 & 0,04 & 2,9 & 6,65 & 1 & 0,88 & \\
\hline & 256,8 & 0,35 & 6,06 & 0,62 & 0,97 & 4,61 & 0,05 & 8,12 & 4,05 & 0,77 & 0,76 & \\
\hline & 257,6 & 0,33 & 5,96 & 0,72 & 0,94 & 5,88 & 0,03 & 13,3 & 4,55 & 0,67 & 0,99 & \\
\hline & 258 & 0,35 & 6,26 & 1,01 & 1,11 & 6,75 & 0,05 & 11,2 & 5,01 & 0,65 & 1,08 & \\
\hline & 258,4 & 0,33 & 5,7 & 0,86 & 0,95 & 6,07 & 0,04 & 1,41 & 4,08 & 0,59 & 1,06 & \\
\hline & 271,2 & 0,45 & 7,22 & 0,63 & 0,97 & 3,99 & 0,05 & 0,59 & 4,42 & 0,96 & 0,55 & \\
\hline & MAG-1 & 0,45 & 8,79 & 0,98 & 1,83 & 4,83 & 0,09 & & & & & \\
\hline & SCo-1 & 0,37 & 6,52 & 1,83 & 1,44 & 3,62 & 0,05 & & & & & \\
\hline
\end{tabular}


Table 2. Trace elements (in ppm), enrichment factors, and $\mathrm{Cu} / \mathrm{Mo}$ and $\mathrm{Mo} / \mathrm{TOC}\left(\mathrm{x} 10^{-4}\right)$ ratios in samples of the Irati Formation. (See Figure 1 for locations; sample labels refer to depth down core in meters).

\begin{tabular}{|c|c|c|c|c|c|c|c|c|c|c|c|c|c|c|c|c|c|c|c|}
\hline Core & Sample & $\mathbf{V}$ & $\mathrm{Cr}$ & Co & $\mathbf{N i}$ & $\mathrm{Cu}$ & $\mathrm{Zn}$ & Mo & U & $E F_{v}$ & $\mathbf{E F}_{\mathrm{cr}}$ & $\mathrm{EF}_{\mathrm{co}}$ & $\mathrm{EF}_{\mathrm{Ni}}$ & $\mathrm{EF}_{\mathrm{Cu}}$ & $E F_{\mathrm{zn}}$ & $\mathrm{EF}_{\text {Mo }}$ & $\mathrm{EF}_{\mathrm{u}}$ & $\begin{array}{l}\mathrm{Cu} / \\
\mathrm{Mo}\end{array}$ & $\begin{array}{c}\text { Mo/TOC } \\
\left(\times 10^{-4}\right)\end{array}$ \\
\hline \multirow{6}{*}{ CA-53 } & 261,7 & 70 & 48 & 13 & 24,2 & 29,4 & 48,6 & 6,6 & 5,7 & 0,6 & 0,6 & 0,8 & 0,4 & 0,7 & 0,6 & 5,7 & 2,1 & 4,45 & 12,41 \\
\hline & 271,4 & 107 & 64 & 14,7 & 26,7 & 48,4 & 85,2 & 6,4 & 5,7 & 1 & 0,8 & 0,9 & 0,5 & 1,3 & 1 & 5,8 & 2,2 & 7,56 & 9,67 \\
\hline & 276,3 & 65 & 48 & 10,6 & 21,7 & 54,6 & 59,2 & 4,9 & 5 & 0,6 & 0,6 & 0,6 & 0,3 & 1,3 & 0,7 & 4,2 & 1,8 & 11,14 & 6,27 \\
\hline & 291,5 & 78 & 48 & 12,5 & 22,5 & 53,1 & 120 & 4,9 & 4,9 & 0,7 & 0,6 & 0,8 & 0,4 & 1,4 & 1,5 & 4,6 & 2 & 10,84 & 11,67 \\
\hline & 294,7 & 93 & 58 & 10,3 & 23,7 & 6,3 & 4,1 & 4,6 & 5,3 & 1 & 0,9 & 0,7 & 0,5 & 0,2 & 0,1 & 4,9 & 2,4 & 1,37 & 9,29 \\
\hline & 298,6 & 132 & 68 & 14,8 & 17,6 & 44,9 & 548 & 18,7 & 9,4 & 1,2 & 0,9 & 0,9 & 0,3 & 1,2 & 6,8 & 17,1 & 3,7 & 2,4 & 11,61 \\
\hline \multirow{9}{*}{ CA-79 } & 595,3 & 109 & 46 & 14,8 & 27,3 & 29,4 & 49,2 & 4,4 & 5,4 & 1 & 0,6 & 1 & 0,5 & 0,8 & 0,6 & 4,3 & 2,3 & 6,68 & 15,07 \\
\hline & 636,1 & 120 & 50 & 13 & 25,2 & 43,2 & 87 & 3,9 & 5 & 1 & 0,6 & 0,8 & 0,4 & 1,1 & 1 & 3,4 & 1,9 & 11,08 & 9,95 \\
\hline & 681,4 & 92 & 55 & 9,2 & 21,4 & 40,6 & 87,2 & 6,7 & 5,3 & 0,9 & 0,8 & 0,6 & 0,4 & 1,2 & 1,2 & 6,8 & 2,3 & 6,06 & 12,98 \\
\hline & 685,5 & 94 & 39 & 7,9 & 38,3 & 36,2 & 74,2 & 7,5 & 8,3 & 0,9 & 0,5 & 0,5 & 0,7 & 1 & 1 & 7,1 & 3,4 & 4,83 & 24,43 \\
\hline & 694,7 & 83 & 49 & 16 & 24,5 & 43 & 71,9 & 6 & 4,8 & 0,9 & 0,8 & 1,2 & 0,5 & 1,4 & 1,1 & 6,8 & 2,3 & 7,17 & 10,91 \\
\hline & 698,3 & 99 & 61 & 14 & 28,4 & 28,8 & 55,3 & 7,2 & 5,8 & 0,9 & 0,8 & 0,9 & 0,5 & 0,8 & 0,7 & 6,8 & 2,4 & 4 & 12,2 \\
\hline & 723,6 & 104 & 72 & 19 & 34,9 & 28,1 & 87 & 6,2 & 5,2 & 0,9 & 0,9 & 1,1 & 0,6 & 0,7 & 1 & 5,2 & 1,9 & 4,53 & 4,96 \\
\hline & 728,5 & 85 & 43 & 13,2 & 22,4 & 10,5 & 47,4 & 4,6 & 4,8 & 0,8 & 0,6 & 0,9 & 0,4 & 0,3 & 0,6 & 4,5 & 2 & 2,28 & 12,89 \\
\hline & 730,5 & 61 & 53 & 12,4 & 24,2 & 19,7 & 31,1 & 5,2 & 4,5 & 0,6 & 0,7 & 0,8 & 0,4 & 0,5 & 0,4 & 4,8 & 1,8 & 3,79 & 15,76 \\
\hline \multirow{7}{*}{ CA-87 } & 437,5 & 76 & 31 & 11,2 & 20,3 & 7,2 & 61,8 & 6,8 & 6,4 & 0,8 & 0,5 & 0,8 & 0,4 & 0,2 & 0,9 & 7,4 & 3 & 1,06 & 37,57 \\
\hline & 489,6 & 114 & 51 & 12,8 & 27,5 & 44,5 & 82 & 4,9 & 5,4 & 1 & 0,7 & 0,8 & 0,5 & 1,2 & 7 & 4,4 & 2,1 & 9,08 & 11,48 \\
\hline & 500 & 55 & 35 & 14,7 & 24,9 & 27,2 & 36,3 & 6,1 & 4,4 & 0,7 & 0,6 & 1,2 & 0,6 & 0,9 & 0,6 & 7,4 & 2,3 & 4,46 & 11,34 \\
\hline & 507 & 101 & 55 & 14,1 & 27,3 & 42,2 & 84,5 & 5,3 & 5,8 & 0,8 & 0,7 & 0,8 & 0,5 & 1,1 & 1 & 4,6 & 2,2 & 7,96 & 12,83 \\
\hline & 512 & 92 & 51 & 10,9 & 23,1 & 41,8 & 86,9 & 7,2 & 6,3 & 0,8 & 0,7 & 0,7 & 0,4 & 1,1 & 1,1 & 6,5 & 2,5 & 5,81 & 11,27 \\
\hline & 516 & 93 & 56 & 24,6 & 58,2 & 41,2 & 51,3 & 8,6 & 5,6 & 0,9 & 0,8 & 1,68 & 1 & 1,1 & 0,7 & 8,1 & 2,3 & 4,79 & 11,41 \\
\hline & 520,2 & 86 & 47 & 15,5 & 31,6 & 33,7 & 53,8 & 7,8 & 5,1 & 0,9 & 0,7 & 1,1 & 0,6 & 1 & 0,8 & 8 & 2,3 & 4,32 & 13,24 \\
\hline \multirow{23}{*}{ HV-44 } & 232 & 111 & 56 & 11,7 & 22,7 & 36,7 & 88,5 & 4,3 & 4,2 & 0,9 & 0,7 & 0,7 & 0,4 & 0,9 & 1 & 3,7 & 1,5 & 8,53 & 5,97 \\
\hline & 233 & 107 & 52 & 20 & 27,3 & 27,2 & 74,5 & 7,5 & 9,3 & 1 & 0,7 & 1,3 & 0,5 & 0,8 & 1 & 7,3 & 3,9 & 3,63 & 1,97 \\
\hline & 234 & 105 & 41 & 13,7 & 17,9 & 27,4 & 33,8 & 6,4 & 7 & 1 & 0,6 & 0,9 & 0,3 & 0,8 & 0,4 & 6,2 & 2,9 & 4,28 & 0,91 \\
\hline & 235 & 111 & 52 & 19,4 & 25,7 & 25,1 & 80,2 & 10,2 & 7,4 & 1,2 & 0,8 & 1,4 & 0,5 & 0,8 & 1,2 & 10,9 & 3,4 & 2,46 & 2,38 \\
\hline & 236 & 73 & 32 & 11,5 & 15 & 13,7 & 47,2 & 6,1 & 8,9 & 0,6 & 0,4 & 0,7 & 0,2 & 0,3 & 0,6 & 5,3 & 3,4 & 2,25 & 2,14 \\
\hline & 238 & 85 & 36 & 10,9 & 13,1 & 21 & 50,3 & 7,9 & 10,2 & 0,9 & 0,6 & 0,8 & 0,3 & 0,7 & 0,8 & 8,8 & 4,9 & 2,66 & 7,75 \\
\hline & 249,6 & 98 & 48 & 12,1 & 28,2 & 33,1 & 80,3 & 5,5 & 5,4 & 0,8 & 0,6 & 0,7 & 0,4 & 0,8 & 0,9 & 4,5 & 1,9 & 6,02 & 11,7 \\
\hline & 250,8 & 115 & 65 & 17,9 & 34 & 36,4 & 91,8 & 5 & 4,3 & 1 & 0,8 & 1,1 & 0,6 & 0,9 & 1,1 & 4,3 & 1,6 & 7,28 & 1,63 \\
\hline & 252 & 118 & 57 & 17,3 & 37,8 & 40,3 & 56,7 & 6 & 5,2 & 1 & 0,7 & 1 & 0,6 & 1 & 0,7 & 5,3 & 2 & 6,72 & 9,23 \\
\hline & 253,2 & 115 & 55 & 18,1 & 32,2 & 35,3 & 51,8 & 5,6 & 5,5 & 1 & 0,7 & 1,1 & 0,6 & 0,9 & 0,6 & 5,1 & 2,1 & 6,3 & 3,59 \\
\hline & 253,6 & 128 & 52 & 17,4 & 29,4 & 36,6 & 35,4 & 10 & 4,6 & 1,5 & 0,9 & 1,4 & 0,6 & 1,2 & 0,6 & 11,6 & 2,3 & 3,66 & 1,62 \\
\hline & 254 & 141 & 51 & 21,4 & 31,4 & 35,9 & 85 & 14,1 & 6,8 & 1,8 & 0,9 & 1,9 & 0,8 & 1,3 & 1,5 & 18 & 3,7 & 2,55 & 1,49 \\
\hline & 254,8 & 81 & 33 & 14,6 & 15,9 & 21,7 & 70,1 & 10,3 & 7,9 & 0,7 & 0,4 & 0,9 & 0,3 & 0,6 & 0,9 & 9,5 & 3,1 & 2,11 & 5,39 \\
\hline & 255,2 & 86 & 37 & 12,8 & 17,8 & 18,5 & 49,5 & 13,9 & 8,8 & 1 & 0,7 & 1,1 & 0,4 & 0,7 & 0,8 & 17,4 & 4,8 & 1,33 & 1,07 \\
\hline & 255,6 & 130 & 54 & 19,8 & 29 & 75,2 & 121 & 14,4 & 10,6 & 1,3 & 0,8 & 1,4 & 0,6 & 2,2 & 1,7 & 14,6 & 4,6 & 5,22 & 1,43 \\
\hline & 256 & 114 & 51 & 11,8 & 23,8 & 37,9 & 40,6 & 24,3 & 8,8 & 1,4 & 0,9 & 1 & 0,5 & 1,3 & 0,7 & 29,3 & 4,6 & 1,56 & 8,38 \\
\hline & 256,8 & 131 & 50 & 19 & 23,6 & 45,5 & 64,5 & 15,1 & 11,2 & 1,5 & 0,8 & 1,5 & 0,5 & 1,5 & 1 & 17 & 5,5 & 3,01 & 1,86 \\
\hline & 257,6 & 143 & 53 & 18,1 & 27,3 & 56,5 & 61,7 & 18 & 10,3 & 1,6 & 0,9 & 1,4 & 0,6 & 1,9 & 1 & 20,6 & 5,1 & 3,14 & 1,35 \\
\hline & 258 & 120 & 47 & 18 & 26 & 36,4 & 72,6 & 17,3 & 8,6 & 1,3 & 0,7 & 1,3 & 0,5 & 1,1 & 1,1 & 18,9 & 4,1 & 2,1 & 1,54 \\
\hline & 258,4 & 109 & 51 & 20 & 21,5 & 33,9 & 86 & 11 & 6,6 & 1,3 & 0,9 & 1,6 & 0,5 & 1,1 & 1,4 & 13,2 & 3,4 & 3,08 & 7,8 \\
\hline & 271,2 & 94 & 61 & 14,8 & 30 & 32,5 & 54,3 & 4 & 3,3 & 0,9 & 0,8 & 1 & 0,5 & 0,9 & 0,7 & 3,8 & 1,3 & 8,13 & 6,78 \\
\hline & MAG-1 & 164 & 109 & 22,3 & 50,9 & 27,7 & 115,3 & 5,7 & 4,8 & & & & & & & & & & \\
\hline & SCo-1 & 154 & 75 & 11,7 & 26,6 & 26,5 & 84,1 & 4 & 3,6 & & & & & & & & & & \\
\hline
\end{tabular}


analysis, approximately $250 \mathrm{mg}$ sample was weighed into beakers, to which $20 \mathrm{ml}$ of $1 \mathrm{~N} \mathrm{HCl}$ were added, then heated on a hot plate at $90{ }^{\circ} \mathrm{C}$ for 12 hours to dissolve carbonates. The samples were then filtered and the solid residue was transferred to crucibles, dried in an oven at $65^{\circ} \mathrm{C}$ for 12 hours. The dry samples were subsequently analyzed by a LECO C/S Determinator, CS-244. For S analysis, approximately $250 \mathrm{mg}$ of untreated sample was weighed directly into a crucible and analyzed by the LECO Determinator.

Pyrite Fe was calculated based on pyrite stoichiometry $\left[\mathrm{Fe}_{\mathrm{py}}=\mathrm{S}_{\mathrm{py}} \mathrm{x}\right.$ (At.wt.Fe/2xAt.wt.S)]. Pyrite $\mathrm{S}\left(\mathrm{S}_{\mathrm{py}}=\mathrm{S}_{\mathrm{total}}-\mathrm{S}_{\mathrm{org}}\right)$ was calculated from the relation between TOC and organic $S$, where $S_{\text {org }}=0.2 \times$ TOC (Bein et al. 1990).

Nine samples were analyzed for $\delta^{13} \mathrm{C}$ in kerogen. Approximately $2 \mathrm{~g}$ of sample powder was weighed into pyrex vial, and bitumen was extracted with methylene chloride. After the liquid fraction was pipetted out, the sediment was air-dried for 12 hours, and subsequently digested by the $\mathrm{HF}-\mathrm{BF}_{3}$ demineralizing procedure of Robl and Davis (1993). Between 2 and $5 \mathrm{mg}$ of treated sample was weighed into quartz tubes and cupric oxide was added as an oxidant. The tubes were sealed and heated in an oven at $800^{\circ} \mathrm{C}$ for 12 hours. The carbon dioxide produced was purified by distillation in a vacuum line and subsequently analyzed for carbon isotopes with a Finnigan MAT 252 mass spectrometer.

\section{RESULTS}

Geochemical data measured and calculated ratios for 43 samples of the Irati Formation are given in Table 1 (major elements, carbon isotopes, TOC and sulfur content, degree of pyritization, and $\mathrm{Fe}_{\mathrm{T}} / \mathrm{Al}$ ratio) and Table 2 (trace elements, enrichment factors, and $\mathrm{Cu} / \mathrm{Mo}$ and $\mathrm{Mo} /$

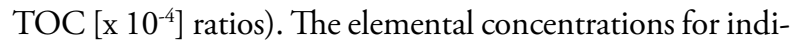
vidual cores indicate a positive correlation between $\mathrm{Ti}$ and $\mathrm{Al}, \mathrm{Cr}$ and V (Fig. 3), implying that these elements were derived from detrital sources, and that $\mathrm{V}$ and $\mathrm{Cr}$ were not measurably enhanced by reduction from the water column. In the cores CA-53, CA-79, and CA-87, there is a positive correlation between $\mathrm{Ca}, \mathrm{Mg}$, and $\mathrm{Mn}$, which exhibit an inverse correlation with elements characteristic of the detrital fraction (Fig. 3), indicating that these are present in the carbonate fraction.

The use of trace element concentrations to reconstruct paleoenvironmental conditions requires an assessment of the degree of enrichment or depletion of a trace element in a

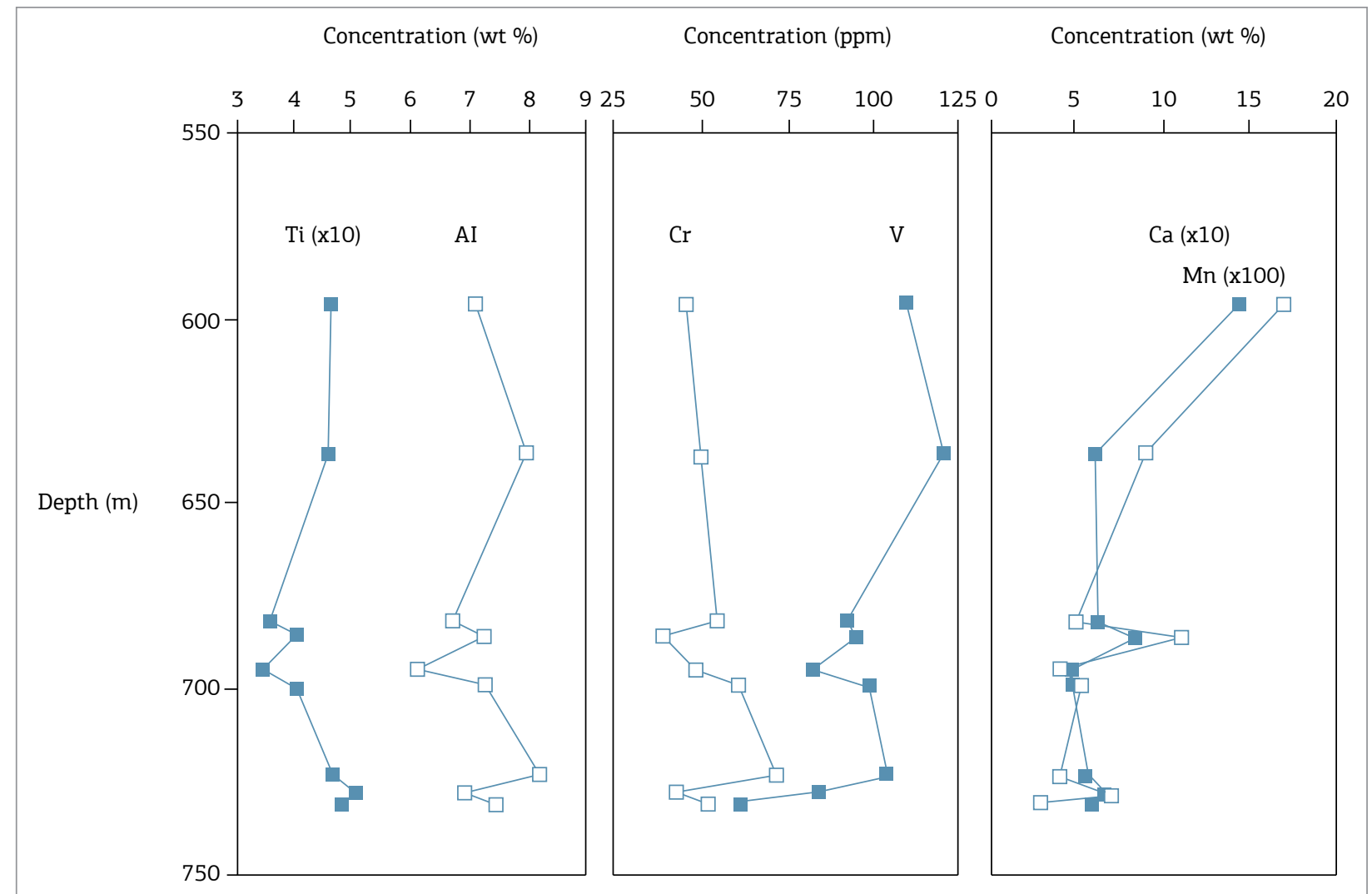

Figure 3. Co-variation between $\mathrm{Ti}, \mathrm{Al}, \mathrm{Cr}$ and $\mathrm{V}$ in samples from core $\mathrm{CA}-79$, which show an inverse correlation with $\mathrm{Ca}$ and $\mathrm{Mn}$. 
sample relative to its concentration in a reference (Tribovillard et al. 2006). We have calculated the enrichment factors (EF) for the analyzed trace elements using the average shale as reference (Wedepohl 1971, 1991). Trace element concentrations were normalized to $\mathrm{Al}$ and enrichment factors were calculated for $\mathrm{V}, \mathrm{Cr}, \mathrm{Co}, \mathrm{Ni}, \mathrm{Cu}, \mathrm{Zn}, \mathrm{Mo}$, and $\mathrm{U}$ according to $\left[\mathrm{EF}_{\text {elem }}=(\mathrm{Elem} / \mathrm{Al})_{\text {sample }} /(\mathrm{Elem} / \mathrm{Al})_{\text {av. shale }}\right]$ (Tribovillard et al. 2006, Huang et al. 2011). Any element with $\mathrm{EF}_{\text {elem }}$ greater than 1 is enriched relative to the average shale, and $\mathrm{EF}_{\text {elem }}$ less than 1 is depleted.

The EFs for the trace elements analyzed in each core are displayed in Figure 4. In all the cores, most trace elements are equal to or depleted in relation to the average shale, except for $U$ and Mo, which are enriched in all the samples. U shows enrichment typically two to three times the average shale, reaching a maximum of five times the average shale in the lower organic-rich bed in core HV-44 (Fig. 4). Mo shows enrichment factors typically between four to five times the average shale, but in the organic-rich beds in core HV-44 Mo enrichment factor varies from six to 29 times the average shale (Fig. 4). The lower and upper organic-rich beds in HV-44 are clearly marked by the enrichment in $\mathrm{U}$ and Mo, which suggest fully anoxic conditions during the deposition of these layers.
To further investigate the relation between Mo enrichment and the presence of anoxic-sulfidic conditions, we compared Mo and TOC concentrations and Mo/TOC ratios in the Irati Formation with those in modern anoxic marine environments studied by Algeo and Lyons (2006). These authors observed that Mo burial fluxes peak in weakly sulfidic environments such as Saanich Inlet, and are lower in strongly sulfidic environments such as the Black Sea and Framvaren Fjord (Algeo and Lyons 2006).

The Mo-TOC plot for the Irati Formation shows that most samples have very low Mo and TOC concentrations in comparison with modern anoxic marine environments (Fig. 5). The most organic-rich samples from core HV-44 scattered along a regression line with very low slope, even lower than that of sediments from the Black Sea (Fig. 5). This indicates that the depositional environment of the Irati shales was limited in Mo but not in organic carbon, implying a strongly anoxic water column.

$\mathrm{Mo} / \mathrm{TOC}$ ratios are useful for distinguishing degrees of restriction in anoxic marine environments (Algeo and Lyons 2006). Values of Mo/TOC $\left(\times 10^{-4}\right)$ greater than 35 are indicative of weakly restricted environments, values between 15 and 35 of moderately restricted, and less than 15 of strongly restricted, sulfidic environments (Algeo and Lyons 2006).

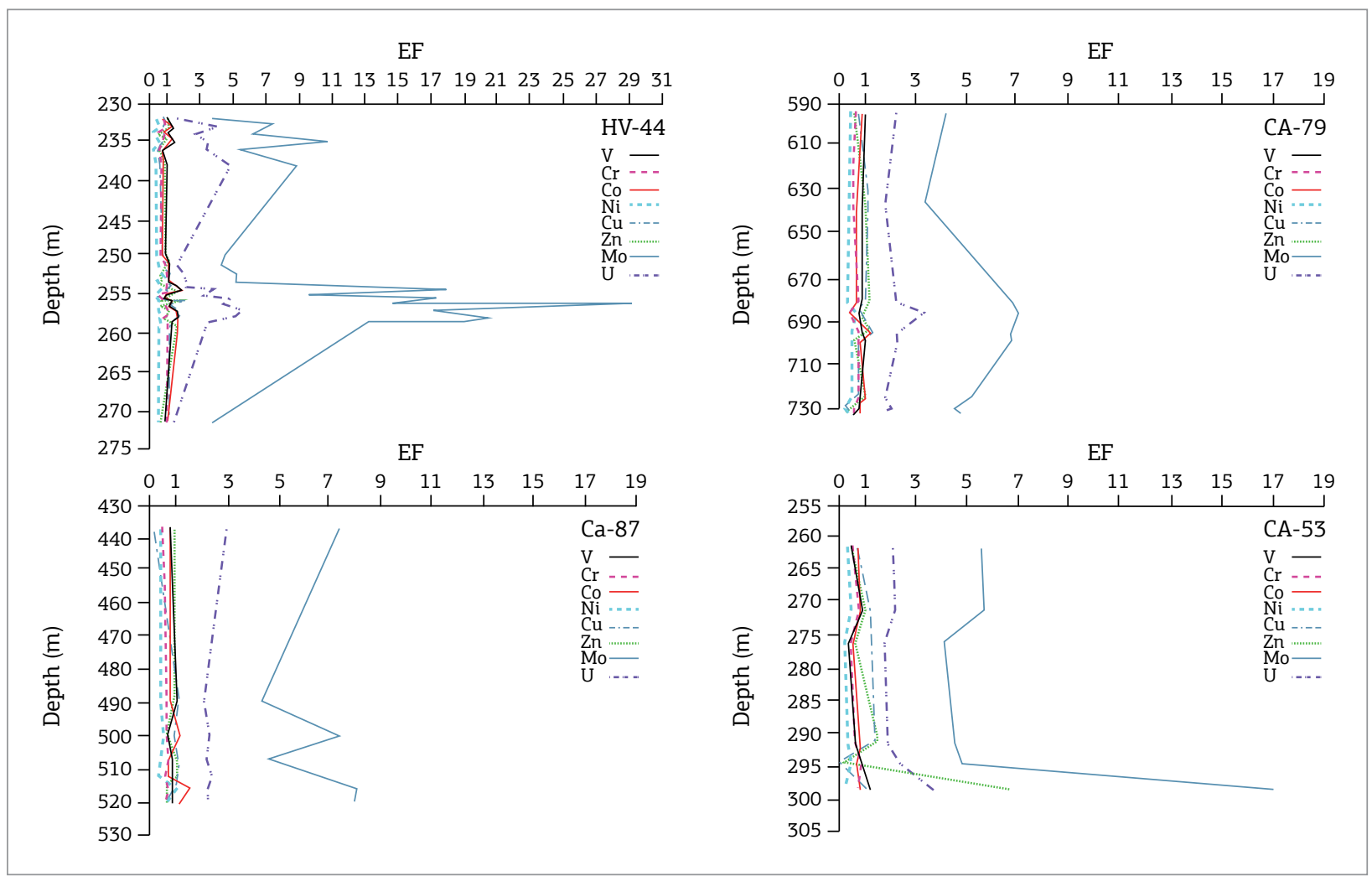

Figure 4. Enrichment factors for the redox-sensitive elements in the Irati Formation along the studied cores. Depths in which the samples were collected are in meters. 
The Mo/TOC ratios calculated for the analyzed samples show that all but three of them (one from CA-87 and two others from CA-79) are lower than 15 (Fig. 6), suggesting that the Irati shales were deposited under strongly restricted,

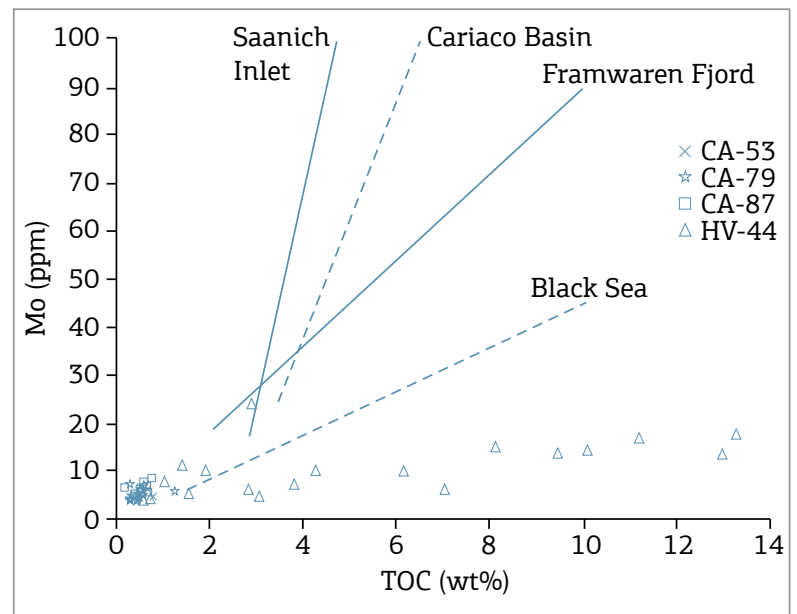

Figure 5. Scatter plot showing the relation between Total Organic Carbon (in wt \%) and Mo (in ppm) for the samples collected from the studied cores in the Irati Formation. Regression lines for four modern anoxic marine environments (Saanich Inlet, Cariaco Basin, Framvaren Fjord and Black Sea) from Algeo and Lyons (2006). sulfidic conditions. The positive co-variation between Mo and TOC (especially in HV-44 samples) implies that most Mo resides in the organic matter (Algeo and Lyons 2006).

The use of $\mathrm{Cu}$ concentration and $\mathrm{Cu} / \mathrm{Mo}$ ratios may shed light on whether the reducing conditions (and consequently enrichment in redox-sensitive elements) were triggered by restricted watermass renewal or stagnation, or by increased organic flux (i.e. increased paleoproductivity). In the presence of a high organic flux, $\mathrm{Ni}$ and $\mathrm{Cu}$ are typically enriched in the sediments, but not Mo (Tribovillard et al. 2006). Under strongly anoxic, sulfidic conditions, $\mathrm{Cu}, \mathrm{U}$, and $\mathrm{V}$, plus Mo in the case of euxinic conditions, are enriched in the sediments (Tribovillard et al. 2006). The plot between $\mathrm{Cu}$ concentration and $\mathrm{Cu} / \mathrm{Mo}$ ratio in the samples from the Irati Formation display a positive co-variation (Fig. 7), suggesting that the enrichments in these redox-sensitive elements were due to increased organic flux rather than prior bottom-water anoxia, since the Mo concentration is approximately constant.

TOC, $S$, and Fe contents were used to calculate the degree of pyritization $\left(\mathrm{DOP}_{\mathrm{T}}\right.$ ) and $\mathrm{Fe}_{\mathrm{T}} / \mathrm{Al}$ ratio (Algeo and Maynard 2008, Lyons and Severmann 2006) (Table 1). All the samples from the Irati Formation in the cores CA-53, CA-79, and CA-87, except for one in CA-87, have low $\mathrm{DOP}_{\mathrm{T}}$ values $(<0.3)$

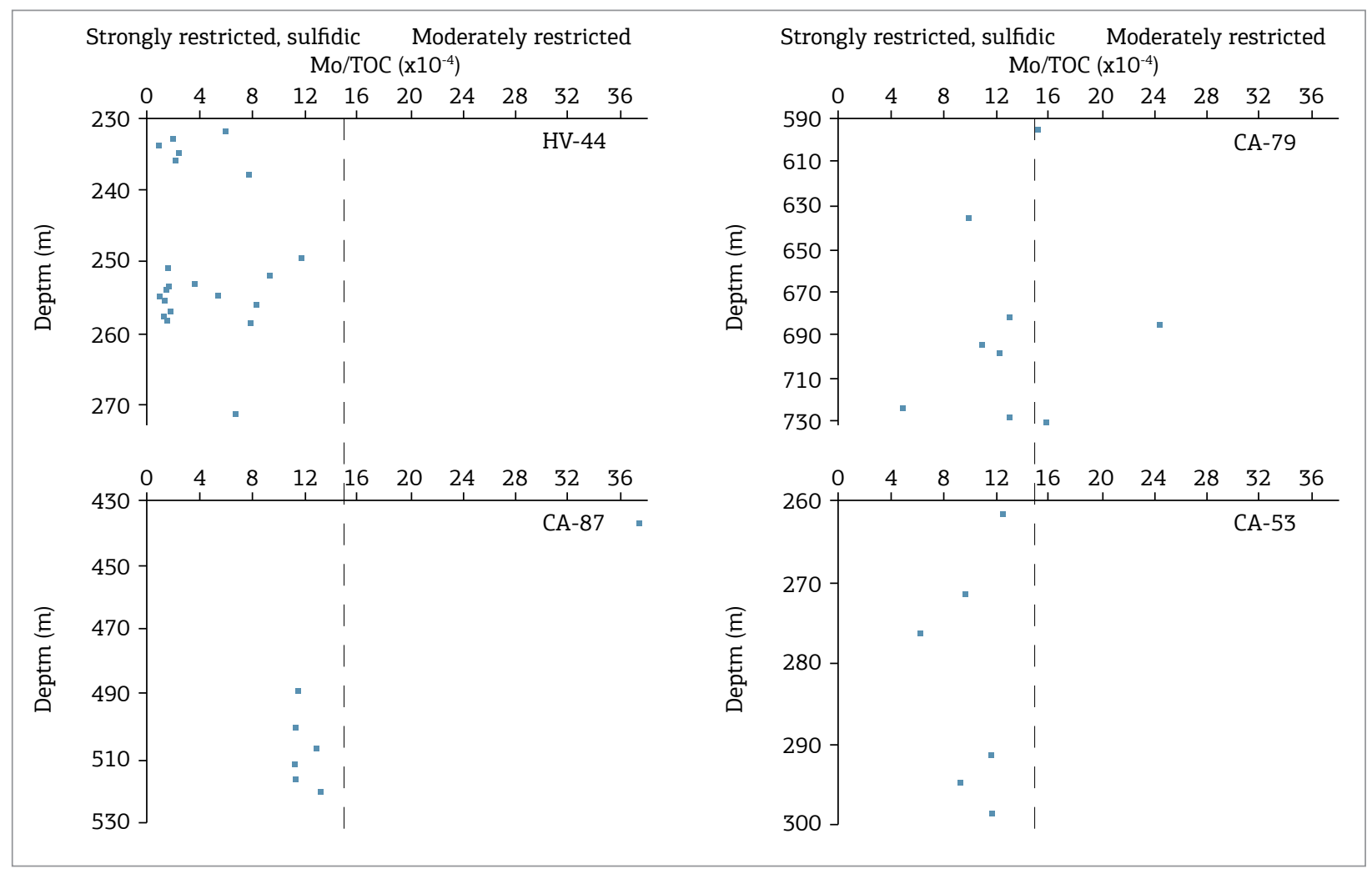

Figure 6. Mo/TOC $\left(x 10^{-4}\right)$ ratios in the Irati Formation along the studied cores. Depths at which the samples were collected are given in meters. The dashed line is $\mathrm{Mo} / \mathrm{TOC}\left(\mathrm{x} 10^{-4}\right)=15$, limiting moderately restricted and strongly restricted, sulfidic environments (Algeo and Lyons 2006). 
(Fig. 8), which suggests deposition under aerobic conditions (Algeo and Maynard 2008). These samples have low TOC contents (Fig. 9). One sample from CA-87 and most samples from $\mathrm{HV}-44$ display $\mathrm{DOP}_{\mathrm{T}}$ between 0.3 and 0.6 , compatible with a restricted environment. The intermediate $\mathrm{DOP}_{\mathrm{T}}$ could be due to reducing conditions in pore waters beneath oxygenated bottom waters, or euxinic deposition at sites with high sedimentation rates (Lyons and Severmann 2006). As sedimentation rates were

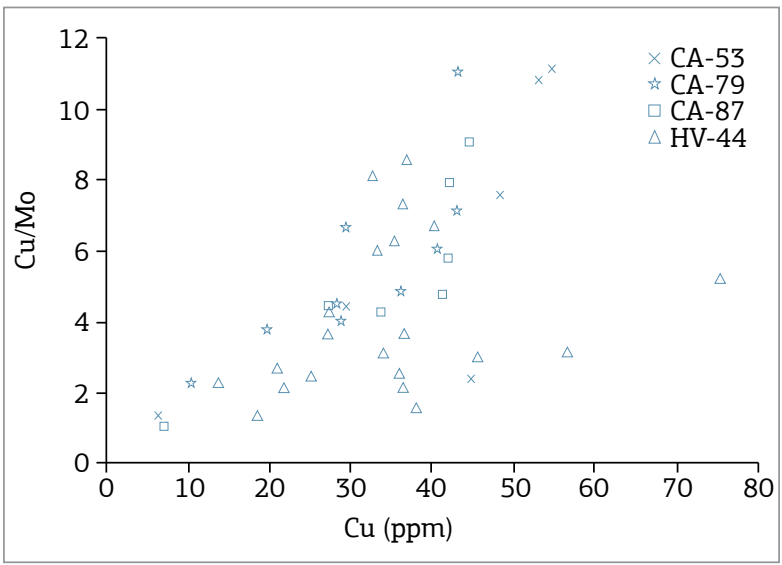

Figure 7. Plot of $\mathrm{Cu}$ concentration (in ppm) and $\mathrm{Cu} / \mathrm{Mo}$ ratio for the Irati samples in the studied cores. low during the deposition of the Irati Formation, the intermediate $\mathrm{DOP}_{\mathrm{T}}$ values are probably indicative of pore-water anoxia beneath oxygenated bottom waters. Three samples from core $\mathrm{HV}-44$ have $\mathrm{DOP}_{\mathrm{T}}$ less than 0.3 , and the samples collected in the lower, organic-rich bed in this core display $\mathrm{DOP}_{T}$ greater than 0.6 , suggesting that during the deposition of this bed the conditions were inhospitable (Algeo and Maynard 2008).

For higher TOC contents samples from the core HV-44, the observation that the $\mathrm{DOP}_{\mathrm{T}}$ is approximately constant $(0.5-0.7)$ over varying amounts of organic matter (Fig. 9) points to an iron-limited environment (Raiswell and Berner 1985), suggesting that the main sulfur sink is organic matter rather than pyrite (Bein el al. 1990). Under these circumstances, there is a good correlation between Fe and $\mathrm{S}$ content, as in the case displayed in figure 10. The fact that all the data from HV-44 plot along a line with slope greater than the pyrite line in the Fe-S diagram (Fig. 10) is yet another evidence of Fe limitation.

$\mathrm{Fe}_{\mathrm{T}} / \mathrm{Al}$ ratios for the Irati Formation are variable in the samples from the different cores studied (Fig. 11). Most samples from the core CA-53 have $\mathrm{Fe}_{\mathrm{T}} / \mathrm{Al}$ between 0.4 and 0.5 , with only one sample greater than 0.5 , suggesting dominantly suboxic conditions (Lyons and Severmann 2006, Algeo and Maynard 2008). $\mathrm{Fe}_{\mathrm{T}} / \mathrm{Al}$ ratios from the core

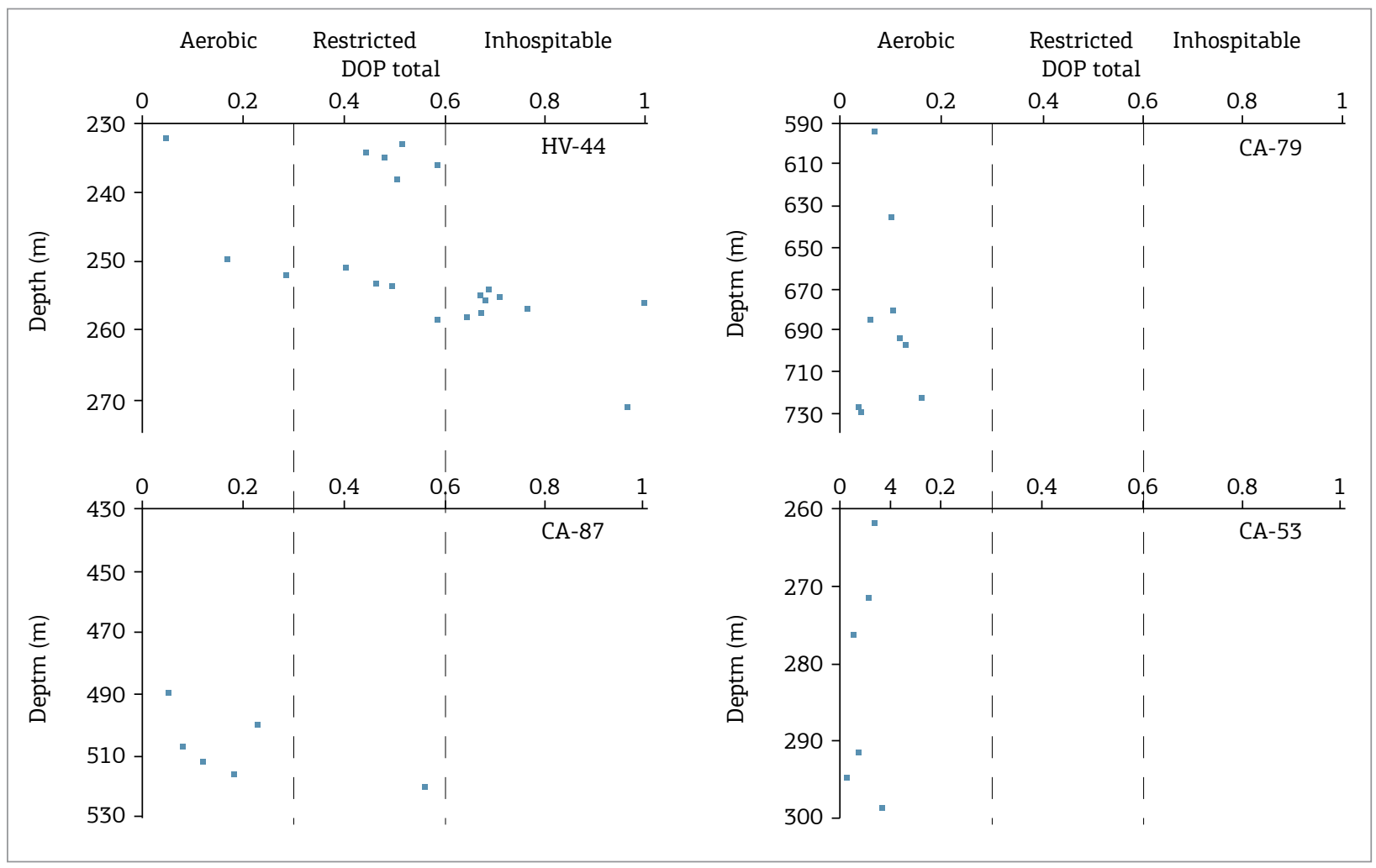

Figure 8. Degree of Pyritization in the Irati Formation along the studied cores. Depths at which the samples were collected are given in meters. The dashed lines indicate Degree of Pyritization equals to 0.3 and 0.6, which limit the fields of aerobic, restricted and inhospitable conditions (Algeo and Maynard 2008). 
CA-79 are highly variable, with most samples displaying ratios less than 0.4 and some equal to or greater than 0.5 , attesting varying degree of oxygenation. All the samples in the core CA-87 display $\mathrm{Fe}_{\mathrm{T}} / \mathrm{Al}$ greater than 0.4 , indicating suboxic to anoxic conditions (Lyons and Severmann 2006, Algeo and Maynard 2008). In $\mathrm{HV}-44, \mathrm{Fe}_{\mathrm{T}} / \mathrm{Al}$ ratios in almost all the samples are greater than 0.5 , some between 0.4 and 0.5 , and only one sample displays $\mathrm{Fe}_{\mathrm{T}} / \mathrm{Al}$ less than

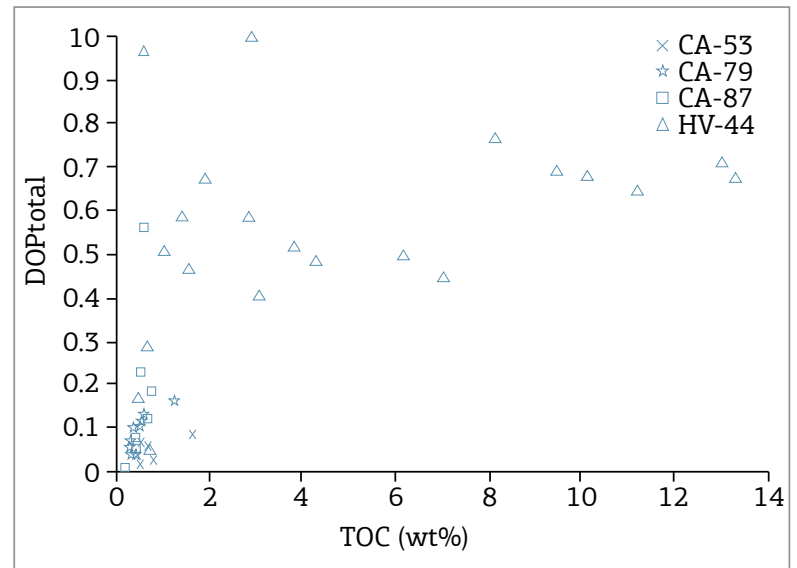

Figure 9. Plot of Total Organic Carbon versus Degree of Pyritization for the Irati samples in the studied cores.
0.4 , thus indicating suboxic to anoxic conditions (Lyons and Severmann 2006, Algeo and Maynard 2008), especially in samples from the two organic-rich beds, which display very high $\mathrm{Fe}_{\mathrm{T}} / \mathrm{Al}$ (Fig. 11).

It is clear from the results reported above that the black shales in the Permian Irati Formation are far from homogeneous. The data suggest that most of the thickness of the Irati Formation is actually composed of rocks with less than $1 \%$ organic carbon, representing the normal, background sedimentation in the basin. The oil shales are restricted to

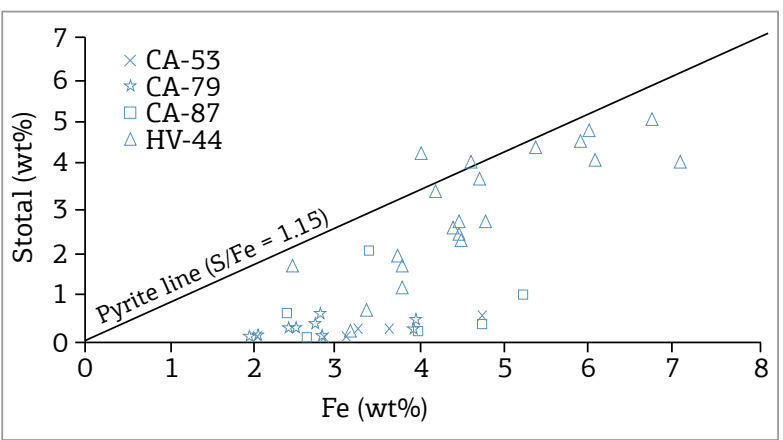

Figure 10. Plot of Fe versus $S$ in samples from the Irati Formation. High Total Organic Carbon samples display a slope greater than the pyrite line.

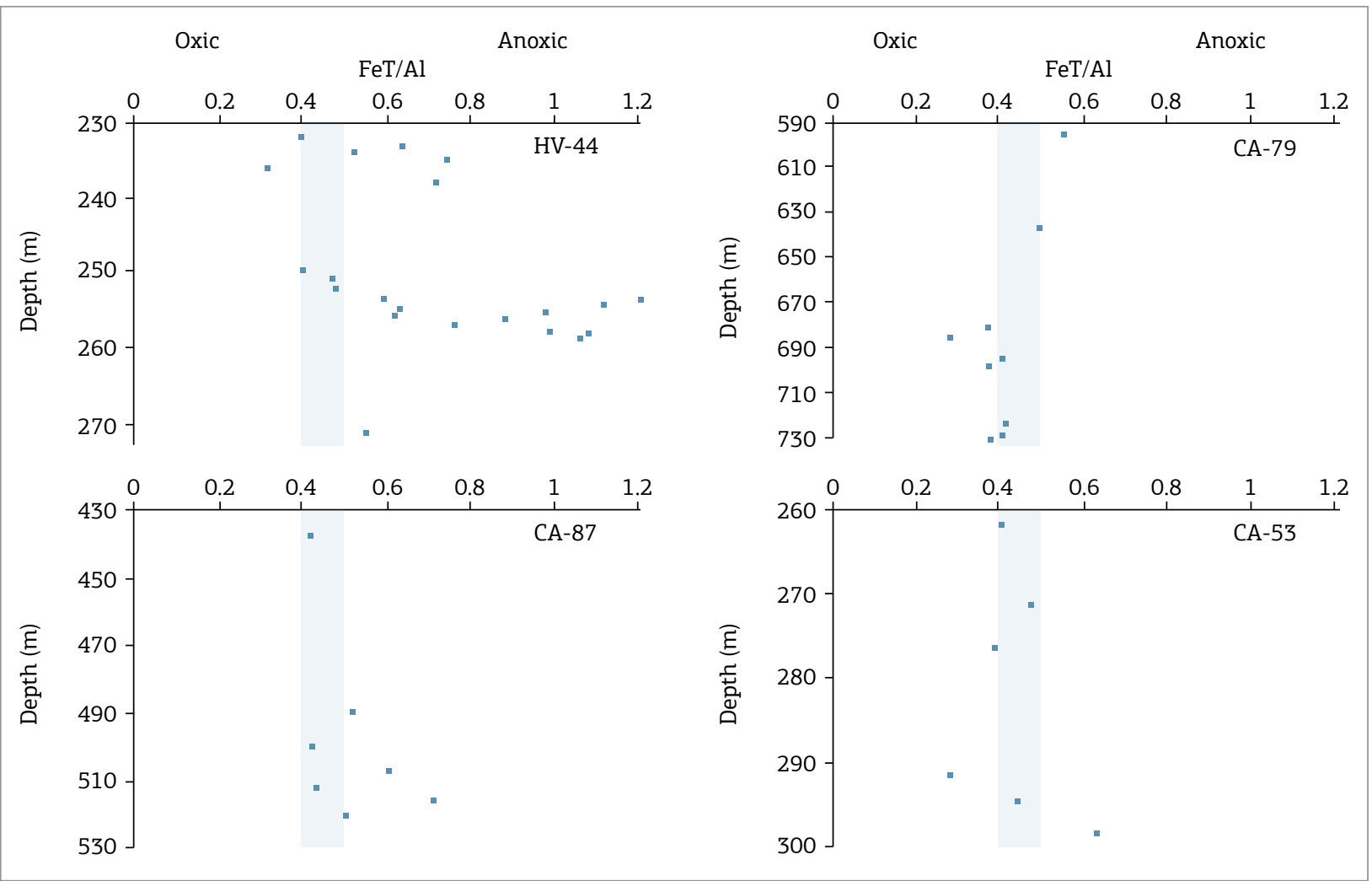

Figure 11. $\mathrm{Fe}_{\mathrm{T}} / \mathrm{Al}$ in the Irati Formation along the studied cores. Depths at which the samples were collected are given in meters. The gray area represents $\mathrm{Fe}_{\mathrm{T}} / \mathrm{Al}$ between 0.4 and 0.5 , which correspond to suboxic conditions (Lyons and Severmann 2006, Algeo and Maynard 2008). 
two main horizons less than $10-\mathrm{m}$ thick (sampled only in the core HV-44), with sporadic increases in TOC detectable only by chance when sampling at coarse intervals (e.g. at depths $298.6 \mathrm{~m}$ in the core CA-53 and $723.6 \mathrm{~m}$ in the core CA-79), since this is not macroscopically or petrographically visible.

\section{Paleoenvironmental reconstruction of the Irati Formation}

Based on the paleoredox proxies applied to the black shales of the Permian Irati Formation (redox-sensitive elements, $\mathrm{DOP}_{\mathrm{T}}$ and $\mathrm{Fe}_{\mathrm{T}} / \mathrm{Al}$ ), we interpret that, during the accumulation of these sediments, the redox boundary was usually located at the sediment-water interface. Trace element enrichment factors suggest that the Irati shales were similar to the average shale, except during the deposition of the two organic-rich beds in the core HV-44, which show great enrichments in $U$ and Mo, thus suggesting that fully anoxic conditions developed during the deposition of these layers. Likewise, the relation between Mo and TOC suggests that bottom waters were anoxic, sulfidic at times, but not permanently anoxic, and that most Mo resides in the organic matter (Algeo and Lyons 2006).

The variable degree of oxygenation of bottom waters is also attested by $\mathrm{DOP}_{\mathrm{T}}$ and $\mathrm{Fe}_{\mathrm{T}} / \mathrm{Al}$. Some samples have low $\mathrm{DOP}_{\mathrm{T}}$ and low $\mathrm{Fe}_{\mathrm{T}} / \mathrm{Al}$ (accompanied by low TOC contents), indicating deposition under aerobic conditions, and some with intermediate $\mathrm{DOP}_{\mathrm{T}}$ and intermediate $\mathrm{Fe}_{\mathrm{T}} /$ $\mathrm{Al}$, indicating a restricted environment. The intermediate $\mathrm{DOP}_{\mathrm{T}}$ probably results from reducing conditions in pore waters beneath oxygenated bottom waters (Lyons and Severmann 2006). Samples in the lower organic-rich bed in $\mathrm{HV}-44$ have high $\mathrm{DOP}_{\mathrm{T}}$ and very high $\mathrm{Fe}_{\mathrm{T}} / \mathrm{Al}$, suggesting inhospitable, anoxic conditions during the depositions of these sediments (Lyons and Severmann 2006, Algeo and Maynard 2008).

The intermittent anoxic conditions in the Irati Formation are also attested by sedimentological indicators of episodic ventilation (probably due to storm activity), such as the presence of interbedded calcarenites with hummocky cross-stratification, silty laminae with small ripples (formed by the migration of small bedforms), and bioclastic lag laminae (indicative of erosion) (Della Fávera 1987, Hachiro 1992, Lavina et al. 1991, Araújo et al. 2004). These characteristics are similar to what was reported for the Posidonia Shale Formation (Early Toarcian) (TrabuchoAlexandre et al. 2012).

The constant $\mathrm{DOP}_{\mathrm{T}}$ over varying amounts of organic matter and the positive correlation between $\mathrm{Fe}$ and $\mathrm{S}$ points to an iron-limited environment (Raiswell and Berner 1985), where the main sulfur sink is organic matter rather than pyrite (Bein et al. 1990).

The results reported above suggest that most of the thickness of the Irati Formation is actually composed of rocks with less than $1 \%$ organic carbon, representing the normal background sedimentation in the basin, with the oil shales restricted to two main horizons (sampled only in core $\mathrm{HV}-44) . \mathrm{DOP}_{\mathrm{T}}$ and $\mathrm{Fe}_{\mathrm{T}} / \mathrm{Al}$, the most reliable indicators of euxinia (Lyons and Severmann 2006), show that euxinic conditions were reached only at times during the deposition of the Irati Formation, and they were responsible for the formation of the intervals richest in organic matter.

The positive correlation between $\mathrm{Cu}$ and $\mathrm{Cu} / \mathrm{Mo}$ ratio suggests that bottom-water anoxia was driven by increased organic flux. The hypothesis that primary productivity blooms led to the accumulation of the Irati organic-rich muds is supported by evidence provided by Araújo (2001). This evidence includes:

1. the overwhelming predominance of amorphous organic matter in the organic-rich horizons (constituting - $92 \%$ of the organic matter) as opposed to its contribution in organic-poor rocks (about $2 \%$ of the organic matter). Amorphous organic matter is believed to be algal in origin, and thus its disproportionate contribution in the organic-rich beds is taken as an indication of algal blooms. The occurrence of algal blooms is supported by the more positive $\delta^{13} \mathrm{C}$ values of TOC, increased from $-27 \%$ o to between -25 and $-22 \%$ in the organic-rich beds (Araújo 2001). Amorphous organic matter is also a very labile component, easily degraded by aerobes, and together with the high hydrogen index of the organic matter (> $500 \mathrm{mg} \mathrm{HC/g}$ TOC) in the organic-rich sediments, points to a higher degree of preservation;

2. the increase in the biomarkers pristane and phytane in the organic-rich shales, which implies a better preservation of chlorophyll, the precursor of both isoprenoids (Araújo 2001). This suggests that high organic carbon rain overwhelmed the capacity of heterotrophic organisms to consume labile organic carbon, which then was preserved in the sediments under conditions of bottom-water anoxia (Araújo 2001);

3. the change in the sedimentary fabric, from bioturbated to laminated, that characterizes the organic-rich beds also attests to bottom-water anoxia (Mello et al. 1993, Araújo et al. 2004). The increase in bottom-water anoxia or the stratification of the water column during the deposition of the organic-rich layers is supported by a number of biomarkers. For example, the increase in pentametileicosane $\left(\mathrm{i}-\mathrm{C}_{25}\right)$, squalane $\left(\mathrm{i}-\mathrm{C}_{30}\right)$, gammacerane and in the $\mathrm{C}_{30}$ moretane/ $\mathrm{C}_{30}$ hopane ratio, as well as the decrease in the pristane/phytane ratio (Araújo 2001). 
Even though there seems to be strong evidence to support the idea that an increase in primary productivity led to bottom-water anoxia and the accumulation of the organic-rich sediments of the Irati Formation, the cause of the productivity bloom is still open. In the case of the Paraná Basin, it is rather unlikely that upwelling played a role in the accumulation of the black shales. The paleogeographic setting of this basin during the Permian was not favorable for coastal upwelling, as during wintertime a low-pressure center would sit over the sea and the winds would push the currents onshore. Basincentered upwelling, on the other hand, is a likely possibility. However, other than the deposition of organic muds, there are no sedimentological indicators of ancient upwelling zones, such as phosphorite deposits and bedded biogenic cherts (Parrish et al. 1983, Parrish 1995). Indeed, a high continental runoff in the Paraná Basin would be a more likely explanation, since during the time of deposition of the Irati Formation the main part of this basin was situated in the mid-latitude humid zone, subject to high precipitation rates.

The Irati Formation was probably deposited in a salinity-stratified body of water, with a positive water balance. The fact that the organic matter in the Irati Formation has a terrestrial component also compares favorably with the scenario described above, the terrestrial constituents being brought in by rivers flowing to the landlocked sea where these sediments were deposited. Stratification is also consistent with data from the fossil and rock record, which includes apparently paradoxical salinity indicators. Fresh water indicators include the crustacean Clarkecaris (Mussa et al. 1980), the algae Botryococcus (Cazzulo-Klepzig et al. 1989), and the fish Xenacanthus pricei (Richter 1985). Marine conditions are indicated by the presence of glauconite pellets (Hachiro et al. 1993, Santos Neto and Cerqueira 1993), commonly associated with polyaxionic sponge spicules (Amaral 1971), the occurrence of the crustacean Paulocaris (Mussa et al. 1980), brachiopods, the ostracode Bairdia sp., foraminifers (Campanha 1985), and acritarchs (Cazzulo-Klepzig et al. 1989). The impoverished fauna is composed of organisms that tolerate low or variable salinity (e.g. Lingula sp. and Paulocaris), suggesting either brackish waters or large salinity fluctuations. Mesosaurids, the swimming reptiles ubiquitous to the Irati and White Hill Formations, did not tolerate severely saline environments (Oelofsen and Araújo 1983). In stratified bodies of water, the vertebrate fauna would probably inhabit the top, relatively fresh water layer (Oelofsen 1987, Oelofsen and Araújo 1983).

\section{CONCLUSIONS}

The geochemical paleoredox indicators in the Irati black shales suggest that:
1. the bottom waters were not persistently anoxic during the deposition of the Irati Formation, but rather oxygen concentrations varied significantly during deposition. The variable degree of oxygenation of bottom waters is attested by $\mathrm{DOP}_{\mathrm{T}}$ and $\mathrm{Fe}_{\mathrm{T}} / \mathrm{Al}$ : samples with low $\mathrm{DOP}_{\mathrm{T}}$ and low $\mathrm{Fe}_{\mathrm{T}} / \mathrm{Al}$ indicating deposition under aerobic conditions, samples with intermediate $\mathrm{DOP}_{\mathrm{T}}$ and intermediate $\mathrm{Fe}_{\mathrm{T}} / \mathrm{Al}$, a restricted environment, and samples with high $\mathrm{DOP}_{\mathrm{T}}$ and very high $\mathrm{Fe}_{\mathrm{T}} / \mathrm{Al}$ (in the lower, organic-rich bed in HV-44) suggest inhospitable, anoxic conditions;

2. trace element enrichment factors in most samples suggest that the Irati shales were similar to the average shale. The most organic-rich beds in the core HV-44 show great enrichments in $\mathrm{U}$ and Mo, indicating that they were deposited under euxinic conditions, in an inhospitable environment;

3. the intermittent anoxic conditions in the Irati Formation are also attested by sedimentological indicators of episodic ventilation, including the presence of interbedded calcarenites with hummocky cross-stratification, silty laminae with small ripples, and bioclastic lag laminae;

4. the Irati Formation was deposited in a salinity-stratified body of water, with a positive water balance predominantly dysoxic to oxic conditions, with episodic, temporary anoxia in the bottom waters. The positive correlation between $\mathrm{Cu}$ and $\mathrm{Cu} / \mathrm{Mo}$ ratio suggests that bottom-water anoxia was driven by increased organic flux (algal blooms). The algal blooms are suggested by the overwhelming predominance of amorphous organic matter, the increase in the biomarkers pristane and phytane, and the change in sedimentary fabric (from bioturbated to laminated) in the organic-rich horizons (Araújo 2001);

5. the main control on the accumulation of the organic-rich rocks of the Irati Formation was increased delivery of organic matter to the sediment as a consequence of high primary production in the water column, probably driven by riverine nutrient input. Anoxia thus probably arose as a consequence of increased productivity, not as the primary driver in the formation of these organic-rich rocks.

\section{ACKNOWLEDGEMENTS}

CNPq (Brazilian Research Council, Grant \# 200453/97-1) is acknowledged for the doctorate scholarship granted to K. Goldberg, and UNISINOS, for the logistics during field work and for the making of thin sections. Field work in Brazil was funded by Sigma Xi, the Department of Geophysical 
Sciences, and the Paleogeographic Atlas Project. Lisa Pratt is thanked for access to the Laboratory of Biogeochemistry at Indiana University - Bloomington. Brazil's Department of Mining and Energy (DNPM/MME) and the Brazilian
Geological Survey (CPRM) are thanked for access to cores and samples. We are greatly in debt to Laury Araújo for the $\mathrm{C}$ isotope and biomarker data provided, and fruitful discussions throughout the development of this study.

\section{REFERENCES}

Algeo T.J., Lyons T.W. 2006. Mo-total organic carbon covariation in modern anoxic marine environments: Implications for analysis of paleoredox and paleohydrographic conditions. Paleoceanography, 21(1):PA1016. DOI:10.1029/2004PA001112.

Algeo T.J., Maynard J.B. 2008. Trace-metal covariation as a guide to water-mass conditions in ancient anoxic marine environments. Geosphere, 4(5):872-887.

Algeo T.J, Schwark L., Hower, J.C. 2004. High-resolution geochemistry and sequence stratigraphy of the Hushpuckney Shale (Swope Formation, eastern Kansas): implications for climato-environmental dynamics of the Late Pennsylvanian Midcontinent Seaway. Chemical Geology, 206(3-4):259-288

Amaral S.E. 1971. Geologia e Petrologia da Formação Irati (Permiano) no Estado de São Paulo. Boletim IGA, 2:03-81.

Anjos C.W.D., Meunier A., Guimarães E.M., El Albani A. 2010. Saponite-rich black shales and nontronite beds of the Permian Irati Formation: sediment sources and thermal metamorphism (Paraná Basin, Brazil). Clays and Clay Minerals, 58(5):606-626.

Araújo L.M. 2001. Análise da Expressão Estratigráfica dos Parâmetros de Geoquímica Orgânica e Inorgânica nas Sequências Deposicionais Irati. PhD Thesis, Programa de Pós-Graduação em Geociências, Universidade Federal do Rio Grande do Sul, Porto Alegre, 302 p.

Araújo L.M., Rodrigues R., Scherer C.M.S. 2004. Interrelação entre a fábrica sedimentar, o conteúdo orgânico e o potencial redox do ambiente deposicional, deduzida das litofácies de rampa distal das sequências deposicionais da Formação Irati, Permiano da Bacia do Paraná. Boletim de Geociências da PETROBRAS, 12(2):429-434.

Arnaboldi M., Meyers P.A. 2007. Trace element indicators of increased primary production and decreased water-column ventilation during deposition of latest Pliocene sapropels at five locations across the Mediterranean Sea. Palaeogeography, Palaeoclimatology, Palaeoecology, 249(3-4): 425-443.

Arthur M.A., Sageman B.B. 1994. Marine black shales: depositional mechanisms and environments of ancient deposits. Annual Review of Earth and Planetary Sciences, 22:499-551.

Bein A., Almogi-Labin A., Sass E. 1990. Sulfur sinks and organic carbon relationships in Cretaceous organic-rich carbonates: implications for evaluation of oxygen-poor depositional environments. American Journal of Sciences, 290:882-911.

Berrocoso A.J., MacLeod K.G., Martin E.E., Bourbon E., Londono C.I., Basak C. 2010. Nutrient trap for Late Cretaceous organic-rich black shales in the tropical North Atlantic. Geology, 38(12):1111-1114.

Brumsack H.-J. 2006. The trace metal content of recent organic carbon-rich sediments: Implications for Cretaceous black shale formation. Palaeogeography, Palaeoclimatology, Palaeoecology, 232(2-4):344-361.

Calvert S.E., Pedersen T.F. 1992. Organic carbon accumulation and preservation in marine sediments: how important is anoxia? In: Whelan J.K., Farrington J.W. (eds.) Organic matter: Productivity, accumulation, and preservation in recent and ancient sediments, New York, Columbia University Press, p. 231-263.
Calvert S.E., Pedersen T.F. 1993. Geochemistry of Recent oxic and anoxic marine sediments: implications for the geological record. Marine Geology, 113(1-2):67-88

Campanha V.A. 1985. Ocorrência de braquiópodes inarticulados na Formação Irati, no Estado de São Paulo. Anuário da Academia Brasileira de Ciências, 57(1):115-116.

Canfield D.E. 1994. Factors influencing organic carbon preservation in marine sediments. Chemical Geology, 114(3-4):315-329.

Carroll A.R., Bohacs K.M. 2001. Lake-type controls on petroleum source rock potential in nonmarine basins. AAPG Bulletin, 85(6):1033-1053.

Cazzulo-Klepzig M., Piccoli A.E.M., Marques-Toigo M. 1989. Reconhecimento de um marco estratigráfico com significado paleoecológico no permiano da Bacia do Paraná (grupos Guatá e Passa Dois). In: $11^{\circ}$ Congresso Brasileiro de Paleontologia, Curitiba, Anais, p. 971-981.

Correa da Silva Z.C., Cornford C. 1985. The kerogen type, depositional environment and maturity of the Irati Shale, Upper Permian of Paraná Basin, southern Brazil. Organic Geochemistry, 8(6):399-411.

Crusius J., Calvert S., Pedersen T., Sage D. 1996. Rhenium and molybdenum enrichments in sediments as indicators of oxic, suboxic and sulfidic conditions of deposition. Earth and Planetary Science Letters, 145(1-4):65-78.

Crusius J., Pedersen T., Calvert S., Cowie G.L., Oba T. 1999. A 35 kyr geochemical record from the Sea of Japan of organic matter flux variations and changes in intermediate water oxygen concentrations. Paleoceanography, 14(2):248-259.

Della Fávera J.C. 1987. Tempestades como agentes de poluição ambiental e mortandade em massa no passado geológico: caso das formações Santana (Bacia do Araripe) e Irati (Bacia do Paraná). Boletim de Geociências da PETROBRAS, 1(2):239-240

Demaison G.J., Moore G.T. 1980. Anoxic environments and oil source bed genesis. AAPG Bulletin, 64(8):1179-1209.

Ekdale A.A., Mason T.R. 1988. Characteristic trace-fossil association in oxygen-poor sedimentary environments. Geology, 16(8):720-723.

Emerson S.R., Huested S.S. 1991. Ocean anoxia and the concentrations of molybdenum and vanadium in seawater. Marine Chemestry, 34(3-4): 177-196.

França A.B., Milani E.J., Schneider R.L., López P.O., López M.J., Suárez S.R., Santa Ana H., Wiens F., Ferreiro O., Rossello E.A., Bianucci H.A., Flores R.F.A., Vistalli M.C., Fernandez-Seveso F., Fuenzalida R.P., Munoz N. 1995. Phanerozoic correlation in southern South America. In: Tankard A.J., Soruco R.S. \& Welsink, H.J. (eds.) Petroleum Basins of South America. AAPG/YPF/Acad. Nac. Ci. Bolivia. AAPG Memoir 62, p. $129-161$.

Gallego-Torres D., Martínez-Ruiz F., Paytan A., Jiménez-Espejo F.., Ortega-Huertas M. 2007. Pliocene-Holocene evolution of depositional conditions in the eastern Mediterranean: Role of anoxia vs. productivity at time of sapropel deposition. Palaeogeography, Palaeoclimatology, Palaeoecology, 246(2-4):424-439. 
Ganeshram R.S., Calvert S.E., Pedersen T.F., Cowie G.L. 1999. Factors controlling the burial of organic carbon in laminated and bioturbated sediments off NW Mexico: implications for hydrocarbon preservation. Geochimica et Cosmochimica Acta, 63(11/12):1723-1734

Goldberg K. 2001. The Paleoclimatic Evolution of the Permian of the Paraná Basin in southern Brazil. PhD Thesis, Department of Geophysical Sciences, University of Chicago, 267 p.

Goldberg T., Strauss H., Guo Q., Liu C. 2007. Reconstructing marine redox conditions for the Early Cambrian Yangtze Platform: Evidence from biogenic sulphur and organic carbon isotopes. Palaeogeography, Palaeoclimatology, Palaeoecology, 254(1-2):175-193.

Hachiro J., Coimbra A.M., Matos S.L.F.1993. O caráter cronoestratigráfico da unidade Irati. In: $1^{\circ}$ Simpósio sobre cronoestratigrafia da Bacia do Paraná, Rio Claro, Resumos, IG-UNESP, p. 62-63.

Hachiro, J. 1992. Bone beds e shell beds como feições diagnósticas de tempestitos da Formação Irati no Estado de São Paulo. In: $37^{\circ}$ Congresso Brasileiro de Geologia, São Paulo, Anais, p. 511-512.

Hatch J.R., Leventhal J.S. 1992. Relationship between inferred redox potential of the depositional environment and geochemistry of the Upper Pennsylvanian (Missourian) Stark Shale Member of the Dennis Limestone, Wabaunsee County, Kansas, U.S.A. Chemical Geology, 99(1-3):65-82.

Huang J., Chu X., Jiang G., Feng L., Chang H. 2011. Hydrothermal origin of elevated iron, manganese and redox-sensitive trace elements in the c. 635 Ma Doushantuo cap carbonate. Journal of the Geological Society, 168(3):805-816.

Joachimski M.M., Ostertag-Henning C., Pancost R.D., Strauss H., Freeman K.H., Littke R., Sinninghe-Damsté J.S., Racki G. 2001. Water column anoxia, enhanced productivity and concomitant changes in d13C and d34S across the Frasnian-Famennian boundary (Kowala Holy Cross Mountains/Poland). Chemical Geology, 175(1-2):109-131.

Jones B., Manning D.A.C. 1994. Comparison of geochemical indices used for the interpretation of palaeoredox conditions in ancient mudstones. Chemical Geology, 111(1-4):111-129.

Kakuwa Y. 2008. Evaluation of palaeo-oxygenation of the ocean bottom across the Permian-Triassic boundary. Global and Planetary Change, 63(1): 40-56.

Lavina E.L., Araujo-Barberena D.C., Azevedo S.A.K. 1991. Tempestades de inverno e altas taxas de mortalidade de répteis mesossauros. Um exemplo a partir do afloramento Passo São Borja, RS. Pesquisas, 18(1):64-70.

Lehmann B.T.F., Nägler T.F., Holland H.D., Wille M., Mao J., Pan J., Ma D., Dulski P. 2007. Highly metalliferous carbonaceous shale and Early Cambrian seawater. Geology, 35(5):403-406.

Lyons T.W., Severmann S. 2006. A critical look at iron paleoredox proxies: New insights from modern euxinic marine basins. Geochimica et Cosmochimica Acta, 70(23):5698-5722.

Mello M.R., Koutsoukos E.A.M., Santos Neto E.V., Silva Telles A.C. Jr. 1993. Geochemical and micropaleontological characterization of lacustrine and marine hypersaline environments from Brazilian sedimentary basins. In: Katz B.G., Pratt L.M. (eds.) Source Rocks in a Sequence Stratigraphic Framework. AAPG Studies in Geology, v. 37, p. 17-34.

Meyers P.A. 2006. Paleoceanographic and paleoclimatic similarities between Mediterranean sapropels and Cretaceous black shales. Palaeogeography, Palaeoclimatology, Palaeoecology, 235(1-3):305-320

Meyers S.R., Sageman B.B., Lyons T.W. 2005. Organic carbon burial rate and the Molybdenum proxy: Theoretical framework and application to Cenomanian-Turonian Oceanic Anoxic Event 2. Paleoceanography, 20(2):PA2002, doi:10.1029/2004PA001068.
Milani E.J., França A.B., Schneider R.L. 1994. Bacia do Paraná. Boletim de Geociências da PETROBRAS, 8(1):69-82.

Milani E.J., Faccini U.F., Scherer C.M.S., Araújo L.M., Cupertino J.A. 1998. Sequences and stratigraphic hierarchy of the Paraná Basin (Ordovician to Cretaceous), Southern Brazil. Boletim IG-USP, Série Científica, 29:125-173.

Milani E.J., Melo J.H.G., Souza P.A., Fernandes L.A., França A.B. 2007. Bacia do Paraná. Boletim de Geociências da PETROBRAS 15(2):265-287

Morford J.L., Russell A.D., Emerson S. 2001. Trace metal evidence for changes in the redox environment associated with the transition from terrigenous clay to diatomaceous sediment, Saanlich Inlet, BC. Marine Geology, 174(1-4):355-369.

Morford J,L,, Emerson S. 1999. The geochemistry of redox sensitive trace metals in sediments. Geochimica et Cosmochimica Acta, 63(11-12):1735-1750.

Morford J.L., Emerson S., Breckel E.J., Kim S.H. 2005. Diagenesis of oxyanions ( $\mathrm{V}, \mathrm{U}, \mathrm{Re}$, and Mo) in pore waters and sediments from a continental margin. Geochimica et Cosmochimica Acta, 69(21):5021-5032.

Mussa D., Carvalho R.G., Santos P.R. 1980. Estudo estratigráfico e paleoecológico em ocorrências fossilíferas da Formação Irati, Estado de São Paulo, Brasil. Boletim IG-USP, 11:142-149.

Oelofsen B.W. 1987. The biostratigraphy and fossils of the Whitehill and Irati shale Formations of the Karoo and Paraná Basins. In: Gondwana Six: Stratigraphy, Sedimentology, and Paleontology, Geophys. Monogr. Ser., 41:131-138.

Oelofsen B., Araújo D.C. 1983. Palaeocological implications of the distribution of mesosaurid reptiles in the Permian Irati sea (Paraná Basin), South America. Revista Brasileira de Geociências, 13(1):1-6.

Parrish J.T. 1995. Paleogeography of Corg-rich rocks and the preservation versus production controversy. In: Huc A.-Y. (ed.) Paleogeography, Paleoclimate, and Source Rocks, AAPG Studies in Geology, 40:1-20.

Parrish J.T., Ziegler A.M., Humphreville R.G. 1983. Upwelling in the Paleozoic Era. In: Thiede J., Suess E. (eds.) Coastal Upwelling: Its Sediment Record (part B), Plenum Press. NATO Conference Series, 10B:553-578,

Pi D.-H., Liu C.-Q. Jiang S.-Y. 2013. Trace and rare earth element geochemistry of black shale and kerogen in the early Cambrian Niutitang Formation in Guizhou province, South China: Constraints for redox environments and origin of metal enrichments. Precambrian Research, 225:218-229.

Piper D.Z., Dean W.E. 2002. Trace-element deposition in the Cariaco Basin, Venezuela Shelf, under sulfate-reducing conditions - A history of the local hydrography and global climate, 20 ka to the present. U.S. Geology Survey Professional Paper 1670. 41p.

Raiswell R., Berner R.A. 1985. Pyrite formation in euxinic and semieuxinic sediments. American Journal of Science, 285:710-724.

Raiswell R., Buckley F., Berner R.A., Anderson T.F. 1988. Degree of pyritization of iron as a paleoenvironmental indicator of bottomwater oxygenation. Journal of Sedentary Research, 58(5):812-819.

Reolid M., Sebane A., Rodríguez-Tovar F.J., Marok A. 2012. Foraminiferal morphogroups as a tool to approach the Toarcian Anoxic Event in the Western Saharan Atlas (Algeria). Palaeogeography Palaeoclimatology Palaeoecology, 323-325:87-99.

Rhoads J.C., Morse J.M. 1971. Evolutionary and ecologic significance of oxygen-deficient marine basins. Lethaia, 4(4):413-428. 
Richter M. 1985. Paleoictiologia no Estado do Rio Grande do Sul, Brasil: características da tafofauna e afloramentos fossilíferos. Iheringia Série Geologia. 19:29-45.

Robl T.L., Davis B.H. 1993. Comparison of the $\mathrm{HF}-\mathrm{HCl}$ and $\mathrm{HF}-\mathrm{BF}_{3}$ maceration techniques and the chemistry of resultant organic concentrates. Organic Geochemistry, 20(2):249-255.

Sageman B.B., Murphy A.E., Werne J.P., Straeten, C.A.V., Hollander D.J,, Lyons T.W. 2003. A tale of shales: the relative roles of production, decomposition, and dilution in the accumulation of organic-rich strata, Middle-Upper Devonian, Appalachian Basin. Chemical Geology, 195(1-4):229-273.

Santos R.V., Souza P.A., Alvarenga C.J.S., Dantas E.L., Pimentel M.M., Oliveira C.G., Araujo L.M. 2006. Shrimp U-Pb zircon dating and palynology of bentonitic layers from the Permian Irati Formation, Paraná Basin, Brazil. Gondwana Research, 9(4):456-463.

Santos Neto E.V., Cerqueira J.R. 1993. Aplicação da geoquímica orgânica na cronoestratigrafia e paleogeografia da Formação Irati, Bacia do Paraná. In: 1 Simpósio sobre Cronoestratigrafia da Bacia do Paraná, Rio Claro, Resumos, p. 71

Sladen C.P. 1994. Key elements during the search for hydrocarbon in lake systems. In: Gierlowski-Kordesch E., Kelts K. (eds.) Global geological record of lake basins, Cambridge, Cambridge University Press, p. 3-17.

Stein M., Westermann S., Adatte T., Matera V., Fleitmann D., Spangenberg J.E., Föllmi K.B. 2012. Late Barremian-Early Aptian palaeoenvironmental change: The Cassis-La Bédoule section, southeast France. Cretaceous Research, 37:209-222.

Trabucho-Alexandre J., Dirkx R., Veld H., Klaver G., de Boer P.L. 2012. Toarcian Black Shales in the Dutch Central Graben: Record of Energetic, Variable Depositional Conditions During An Oceanic Anoxic Event. Journal of Sedimentary Research, 82(2):104-120.
Tribovillard N., Algeo T.J., Lyons T., Riboulleau A. 2006. Trace metals as paleoredox and paleoproductivity proxies: An update. Chemical Geology, 232(1-2):12-32.

Triguis J.A., Araújo L.M., França A.B., Winter W.R. 1996 Depositional environment and sequence stratigraphy of the Irat Formation (Late Permian) Paraná Basin - Brazil. In: $5^{\text {th }}$ Latin American Congress on Organic Geochemistry, Cancun, Annals, p. 219-221.

Tyson R.V., Pearson T.H. 1991. Modern and ancient continental shelf anoxia: an overview. In: Tyson R.V., Pearson T.H. (eds.) Modern and Ancient Continental Shelf Anoxia, Geological Society Special Publications, 58:1-26.

Wedepohl K.H. 1971. Environmental influences on the chemical composition of shales and clays. In: Ahrens L.H., Press F., Runcorn S.K., Urey H.C. (eds.) Physics and Chemistry of the Earth. Oxford, Pergamon, p. 305-333.

Wedepohl K.H. 1991. The composition of the upper Earth's crust and the natural cycles of selected metals. In: Merian E. (ed.) Metals and their Compounds in the Environment. VCH-Verlagsgesellschaft, Weinheim, p. 3-17.

Wignall P.B., Myers K.J. 1988. Interpreting benthic oxygen levels, in mudrocks: a new approach. Geology, 16(5):452-455.

Xiong Z., Li T., Algeo T., Chang F., Yin X., Xu Z. 2012. Rare earth element geochemistry of laminated diatom mats from tropical West Pacific: Evidence for more reducing bottom waters and higher primary productivity during the Last Glacial Maximum. Chemical Geology, 296-297:103-118.

Available at www.sbgeo.org.br 